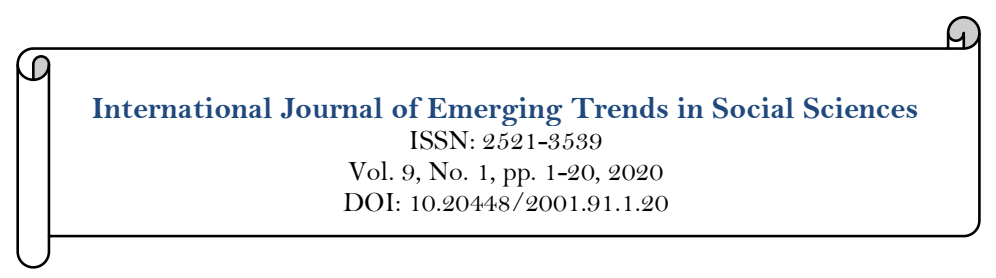

\title{
Survival Strategies in the Spanish ICT Sector: Amper between Two Crises
}

\author{
Angel Calvo \\ Honorary Lecturer, Universitat de Barcelona, Spain. \\ Email:angel.calvo@ub.edu
}

\begin{tabular}{|c|c|}
\hline Abstract & \\
\hline $\begin{array}{l}\text { This article aims to study the performance of an oligopolistic sector through } \\
\text { the case of a medium-sized multinational company, belonging to the } \\
\text { telecommunications equipment industry, at a time of crisis. Its interest lies in } \\
\text { the contrast with a general situation during the first decade of the new } \\
\text { millennium, sealed by the numerical predominance of the small size in the } \\
\text { companies of the planet, on the one hand, and the determining weight of the } \\
\text { big multinational companies. In this sense, it aims to make a contribution to } \\
\text { the debate on the impact of resource and size constraints on the } \\
\text { internationalization of small and medium-sized enterprises (SMEs). It also } \\
\text { seeks to intervene in the controversy over patterns of adaptation to markets } \\
\text { and technological change in general in their struggle for survival. In the } \\
\text { particular facet of internationalization based on foreign direct investment } \\
\text { (FDI), it seeks to delve into the patterns and reasons for SME FDI } \\
\text { defended by traditional theories. The business model based on proprietary } \\
\text { technology and strong internationalisation that Amper exemplifies achieved } \\
\text { irrefutable results in the face of the crisis, but some evidence suggests a return, } \\
\text { insufficiency and unfulfilled results. }\end{array}$ & $\begin{array}{l}\text { Licensed: } \\
\text { This work is licensed under a } \\
\text { Creative Commons Attribution } 4.0 \\
\text { License. } \\
\text { Publisher: } \\
\text { Scientific Publishing Institute } \\
\text { Received: } 17 \text { July } 2020 \\
\text { Revised: } 13 \text { August } 2020 \\
\text { Accepted: } 28 \text { August } 2020 \\
\text { Published: } 11 \text { September } 2020\end{array}$ \\
\hline
\end{tabular}

Funding: This study received no specific financial support.

Competing Interests: The author declares that there are no conflicts of interests regarding the publication of this paper.

Acknowledgement: This study is assigned to the Centre d'Estudis 'Antoni de Capmany' d'Economia i Història Econòmica, Department of Economic History, Institutions and Policy and World Economy, Faculty of Economics and Business (Universitat de Barcelona, Spain). I would like to thank those responsible for supporting my research as well as the editors of this Journal.

\section{Introduction}

This article examines the behaviour of an oligopolistic sector through the case of a medium-sized multinational entreprise (MSME), belonging to the telecommunications equipment industry. It presents an interesting example because it contrasts with a general situation in the chosen period - the first decade of the new millennium - when small size predominant in the world's companies, on the one hand, and that of large companies in multinational businesses ${ }^{1}(\mathrm{Nick}, 1993)$. In this regard, it is a contribution to the debate on the impact of resource and size constraints on the internationalization of small and medium-sized enterprises (SMEs), Kalinic and Forza (2012); Kuo and Li (2003); Urata and Kawai (2000) considered as such according to the economic criterion (Buckley, 1989) as well as the advantages for adapting to markets and technological change in general (Chen \& Hambrick, 1995) and, more precisely, in the more current context of globalization ${ }^{2}$. Do MSMEs have a distinctive trait compared to mainstream multinational companies? (Shin, 1990).

\footnotetext{
${ }^{1}$ Nick Szabo, "Business", 1993, accessed at https://www.google.com/search?client=firefox-b-d\&q=Small++Multinationals.

2 Acs and Yeung (1999). A "globalised" economy is one in which transport and communication costs would be almost zero and in which the barriers created by different national jurisdictions (national states or regional economic organisations) would have disappeared: Wolf (2001). Three processes related to globalization combine to make it difficult for various countries to meet their defence and security needs. These are the rising cost of arms, competition between major multinational arms companies, and finally the internationalisation of component supply chains: Devore (2013). Economic criteria refer to those
} 
In the specific dimension of internationalisation based on foreign direct investment (FDI), it is a contribution to the ways and reasons for MSMEs' FDI advocated by traditional theories. The main ways include the theory of vertical and horizontal FDI based on industrial organization (Caves) and the gradualist innovation model (Johanson and Vahlne). he main causes comprise the theories of monopolistic advantage based on imperfect competition (Hymer), product life cycle (Vernon), trade and investment based on marginal comparative advantage (Kojima), internalization based on transaction cost (Buckley and Casson) and internalization based on the OLI model (Dunning) ${ }^{3}$.

The analysed undertaking carried out its activities during the years 1995-2005 in a general context of fluctuating market conditions. The telecommunications sector invested heavily until 2000, but afterwards, the long-distance operators, immersed in the dot.com bubble, drastically reduced their capital expending and investments. In particular, telephone equipment manufacturers cut capital expending more aggressively and were forced to reduce their activities ${ }^{4}$.

In 2008, the global economic situation suffered a generalised deterioration whose negative impact continued in most developed countries throughout 2009, a year in which "the worst global slowdown in recent history" preceded the current pandemic, as described by ${ }^{5}$ (International Monetary Fund, 2010).

The effects of the crisis varied from sector to sector. The rate of growth in net sales declined across sectors as a whole while it increased in low-R\&D intensity sectors, primarily due to high oil prices in 2008 that favoured oil-related sectors. An extreme degree of this trend was seen in the high R\&D intensity sector in the EU, where net sales grew at less than half the rate achieved by their US counterparts. Market capitalisation declined more sharply in the last period (August 2008 - August 2009) and to varying degrees depending on R\&D intensity. The greatest impact was felt by firms in the upper-middle intensity sectors in the case of the EU and the lower-middle intensity sectors in the case of the USA ${ }^{6}$.

In terms of the impact of the crisis on $\mathrm{R} \& \mathrm{D}$, a subject of great interest in this study, business investment in $\mathrm{R} \& \mathrm{D}$ continued to grow in 2008 , although at a slower rate than the previous year (6.9 per cent instead of 9.0 per cent). The number of companies involved in 2008 was similar in the EU to that outside it. Taking the top 100 companies, there were 55 increases in R\&D of over $5 \%$ and 27 decreases in both areas. R\&D intensity continued to grow at a gradual pace worldwide, with fixed capital investment increasing faster than net sales, EU companies showing the strongest growth in fixed capital investment 7 (European Communities, 2009).

During the second half of 2009 , some signs of recovery began to appear, by no means generalised to the world's economies overall. In Spain, the fall in GDP by almost 3.6\%, the largest drop in the last half century, together with measures to contain public spending, with budget cuts, had a negative impact on businesses as a whole, and the ICT sector in particular. Data from the Spanish Association of Electronics, Computing and Telecommunications Companies show that the fall in investment during the year in the telecommunications industry sub-sector to which Amper belongs contributed to a 24\% drop in turnover ${ }^{8}$ (Annual Report, 2009).

In those turbulent years, remarkable changes took place in the world ranking. By the end of 2009, the top ten IT companies had been joined by Hewlett-Packard of the USA and Toshiba of Japan. The top group included only one of the largest telecommunication equipment companies (NEC) and one of the largest electronics companies (Ericsson) in existence in 2000. Geographically, the list consisted mainly of Chinese companies $^{9}$ (Hoyt, 2001; OECD, 2010).

Going into the structure, the article is organised in three main sections, preceded by an introduction that frames the story and followed by some conclusions. The first section examines growth strategies in liberalised environments, the second refers to strategic alliances and agreements, and the third concerns the accumulation of technological capacity in search of increased competitiveness. The sources used are in substance those of the company studied and, in the official side, those of the National Stock Market Commission (in Spanish CNMV).

\section{Growth Strategies in Liberalised Environments}

It should be added to the outlined framework that the oligopolistic structure of the sector had not changed either. However, one of the aspects that had changed substantially from the generality of the previous stage concerned the immediate socio-economic environment as the sector had reached full liberalization.

Already in the exit phase of the disastrous dot.com bubble in 2004, Amper tripled its net result, while at the same time cleaning up its activity and managing to detach itself from some areas outside the core of the activity.

\footnotetext{
considered by the 1971 Bolton Report: market share not large enough to influence prices, independence and control of the business and personalised management by the owners with a little delegation in the choice of strategy and decision-making: Pu and Zheng (2015). A journal as significant as Small Business Economics seems more interested in topics such as networks, productivity and ecosystems.

${ }^{3}$ Literature review by Pu and Zheng (2015), 63-70. The guidelines include strategies such as divestments, which are of great importance but poorly known and therefore of great interest: Moschieri and Mair (2008), 399-422.

${ }^{4} \mathrm{OECD}$ (2007). Overall, the telecommunications sector reached $\$ 1$ trillion in revenues for the first time in 2005: OECD (2003).

${ }^{5}$ International Monetary Fund (2010), 1-6.

${ }^{6}$ European Communities (2009), p. 39.

${ }_{7}^{7}$ The Scoreboard defines R\&D intensity as the ratio of R\&D to net sales: European Communities (2009), p. 16.

8 Annual Report (2009), p. 20.

${ }^{9}$ Hoyt (2001), pp. 3-4; OECD (2010), p. 59.
} 
The shareholding structure underwent a significant number of changes as a consequence of the departure of some traditional partners in a context of rising trading volumes and share prices. As a direct result of these movements, the telephone operator Telefónica regained its leading position among the group of shareholders. In 2008, Caja de Ahorros de Castilla-La Mancha (CMM) and a new grouping including the family holding company Naropa Capital each held 9.1 per cent of Amper ${ }^{10}$. At the chronological end of this study, the majority shareholder had become CMM, followed by Telefónica, while almost half of the shares - $47.2 \%-$ were on the stock exchange.

\begin{tabular}{l|l|l|c|c|c|c}
\multicolumn{7}{c}{ Table-1. Acquisitions of company holdings. } \\
\hline Company & $\begin{array}{l}\text { Asset or stake } \\
\text { acquired }\end{array}$ & Seller & $\begin{array}{l}\text { Year } \\
\text { acquired }\end{array}$ & $\begin{array}{l}\text { Price } € \\
\text { million }\end{array}$ & Comments \\
\hline Amper & EPICOM, SA & & 100 & 2005 & & cash: 58 \\
\hline Amper & $\begin{array}{l}\text { Landata Ingeniería, } \\
\text { SA }\end{array}$ & $\begin{array}{l}\text { Landata } \\
\text { Ingeniería, } \\
\text { SA }\end{array}$ & 100 & 2006 & 75 & \\
\hline $\begin{array}{l}\text { Hemisferio } \\
\text { Norte SA }\end{array}$ & $\begin{array}{l}\text { additional share of } \\
\text { Medidata } \\
\text { Informática }\end{array}$ & $\begin{array}{l}\text { Medidata } \\
\text { Informática }\end{array}$ & 13.96 & 2006 & 0,742 & \\
\hline Amper & $\begin{array}{l}\text { Sociedad } \\
\text { Telecomunicación e } \\
\text { Instalaciones } \\
\text { (Telcar) }\end{array}$ & Telcar & 100 & 2006 & 23,5 & \\
\hline Amper & FEDETEC & & & & \\
\hline Amper & Knosos, S.L & Knosos, S.L & 100 & 2007 & & \\
\hline Source: Based & & & & & \\
\hline
\end{tabular}

Immediately, Amper began to act on two fronts, the first being cost control, specifically wages, bring the main cost items down to the size of the company. Secondly, Amper aimed to regain a commercial dimension similar to that before the severe crisis of 2001, through a policy of organic growth (new contracts, increased sales, tax and financial optimisation) and corporate growth through selective acquisitions ${ }^{11}$.

As a group, Amper chose different strategies. The most important was to focus and grow in companies that are attractive in the long term, provided they enable it to achieve leadership positions. In this way, its objective was to consolidate its position as one of the national and European leaders in the field of civil and military communications and command and control systems, to optimise synergies in the systems and information technology integration sector and to adapt to the telecommunications operator sector by entering into profitable, high value-added activities.

If we consider units of the group, Amper Programas introduced its products in the demanding Swiss Defence market, as a result of strengthening its export facet, and Amper Sistemas presented its technological solution for border surveillance in markets all over the world Annexe $2^{12}$.

The growth strategy soon turned into the creation of a new company in partnership with Medidata Brazil at 86 and 14 percent, culminating in two previous entry moves to control the Brazilian company. Named Amper Medidata, it started as a centre of excellence in IP, mobility, storage and security communications technologies. The field of systems integration was strengthened shortly afterwards with the acquisition of Telcar and Landata.

Returning to the parent company, various integration and divestment initiatives responded to the strategy of consolidating and strengthening its leadership in the area of security and defence. In the concentration modality, some of them did not reach their culmination. In 2004, Amper withdrew from the agreement of intentions sealed at the beginning of the year with Page Ibérica SA by which the signatories committed to integrating their activities. Amper was to acquire the capital of Page in its entirety through the payment of the value of the shares of PAGE, composed of a combination of cash and newly issued shares, assuming a financial debt ${ }^{13}$. The acquisition of shares in Tecnobit SL was also included in the same type of concentration $^{14}$.

\footnotetext{
${ }^{10}$ El Economista, 17 June 2008; CincoDías, 27 February 2008. Naropa Capital was created from the sale of a real estate entreprise.

${ }^{11}$ Amper (2004a) forecasted a doubling of its turnover in the next two years.

${ }^{12}$ Certain authors (Rosiere \& Jones, 2012) point to the beginning of the new coercive stage of globalization.

${ }^{13}$ The value of PAGE shares was set at $€ 37$ million, cash payment at about $€ 24.8$ million and newly issued shares and net financial debt at $€ 7.4$ million. It was estimated that the operation would generate for AMPER €26 million. PAGE shareholders would subscribe to a capital increase representing $10 \%$ of AMPER's share capital: CNMV, 50.140, 31/5/2004.

14 The total price of 5,640,382.25 was made up of a sum payable in cash - 3.13 euros per holding - and shares in the said newly-issued company. The commitment, signed at the end of 2003 and novated thereafter, established the shares of Tecnobit, S.L. representing $28.87 \%$ of its share capital: CNMV, 47,163 , 30/1/2004. Created in 1985, Tecnobit began by developing the transmission of secret messages for the Ministry of Defence and became one of the largest and most avant-garde companies in professional electronics and avionics in Europe. After the suspension of payments of Eurotrónica, it absorbed part of the contracts of the failed in the Eurofigther project. In 1998, a change of ownership opened the way for takeovers - Sidocor and Elco Sistemas, from the former Ceselsa - with the aim of increasing technological capacity and access to more important programmes. The Spanish CASA, British Aerospace and the
} 
Another axis of the AMPER Group's strategy was to strengthen its position in the area of integration of voice, data and video convergent networks. An outstanding example was the acquisition of Landata Ingeniería Table 1 one of the main communication network engineering companies in the Spanish market, belonging to the Landata Group (Annexe 1). AMPER fully financed the transaction through a 61 million euro bridge loan granted by HSBC Bank. The integration of this entreprise into the AMPER Group meant a leap in size, strength and possibilities for further development of the segment in which it was present ${ }^{15}$.

Amper's own strategy was also to reinforce its position in the design and implementation of security and critical communication networks and systems (Homeland Security). In this area, Amper's main clients were the emergency services, border surveillance, fire brigades, forest brigades and health emergencies.

Towards the end of 2007, it acquired the total capital of Knosos, S.L., a small and dynamic company specialised in the design, manufacture and maintenance of equipment with its own technology in the field of navigation systems, GPS location and data transmission units, remote information access systems for security forces and mobile information management platforms, using PDAs. The objectives were to optimize the performance of the complex Amper systems and to reduce the risks of their integration. This takeover allowed Amper to begin exporting soon the Knosos catalogue across the international sales network of Amper Homeland Security and, moreover, to develop the complementarities of both companies in the international markets in which Knosos had started to operate ${ }^{16}$.

Already towards the end of the period under study, Amper was drawing a line of continuity with the main strategic objectives of the immediate aftermath of the crisis. Such continuity was nuanced because it sought organic growth with a specific goal -doubling in size-, selective internationalization, focusing on business units with high growth potential, and corporate acquisitions ${ }^{17}$. Almost without delay, it stressed the priority of structural adjustment and cost control, and manifested its desire to boost long-term growth and profitability by strengthening innovation and internationalisation. In the first case, it protected margins and gained market share in an increasingly competitive environment. The second, in addition to compensating for the fall in the domestic market, served as an incentive by forcing the level of global excellence in products and services to a $\operatorname{maximum}^{18}$.

In the new 2007 strategic plan, Amper focused on engineering and comprehensive solutions for civil and military communications, always with the target of substantial growth and profitability. This "focus" strategy coupled with major efforts in innovation and internationalisation. During 2007 Amper Programas opened establishments in Albacete and Seville to intervening in the most important aeronautical projects announced in Spain: Eurocopter helicopters in the first city and Airbus helicopters in the Aerópolis of Seville cluster. The company planned to work on the development of the avionics systems for these aircraft with the collaboration of the state, regional and European Union administrations. At the time of its start-up, the Seville centre, located in facilities not belonging to the company, was not very highly qualified, but Amper intended to provide it with an R\&D section and turn it into Thales's logistics centre in Southern Europe ${ }^{19}$.

In 2010, as a reassertion of its profile, Amper defined itself as a Spanish multinational with a long history, specialised in the design and implementation of solutions in the ICT sector and, more specifically, in defence, communications and security activities ${ }^{20}$. Amper simplified its corporate structure with a reformulation of the

\footnotetext{
German Daimler Benz were the main customers of the systems developed by the company, which had 132 employees, all of them industrial and telecommunications engineers and senior technicians: El Mundo, 4 June 2000.

${ }^{15}$ CNMV, 73.975, 18/12/2006. Amper bought all of Landata Ingeniería S. A. from IBV Corporation, which in turn owned $80.1 \%$ of Landata Comunicaciones de Empresa (Ericsson Spain the remaining 19.9\%), all of Landata Ingeniería de Seguridad and 60 \% of Lanaccess Telecom SA: Presentation on the operation, CNMV, 71,302 5/10/2006. Landata designed, implemented and maintained the comprehensive communications solutions (voice, data, video, etc.), both in the telecommunications operator segment and in the business and institutional segment (end users). The Landata Group had a consolidated turnover in 2005 of 84.9 million euros and an EBITDA of $€ 9.2$ million; in $2005,67.7 \%$ of the sales corresponded to products, $20.6 \%$ to services and $11.7 \%$ to maintenance. Landata Ingeniería specialized in the integration of data network solutions and focused on the development of IP networks, digital access and transport networks, HFC networks, video headends and video walls, turnkey projects and network consultancy

${ }_{16}$ With a turnover in 2006 of $€ 6.8$ million and an EBITDA of 1.6 million. The agreed price amounted to a maximum of $€ 16.38$ million (cash: $€ 6.02$ million; deferred and variable amount: $€ 10.36$ million, subject to compliance with various conditions). Mobile networks: TETRA/TETRAPOL, INMARSAT AND GPRS; composition of Knosos' clientele: 3/4 Ministry of the Interior (Directorate-General of Traffic and Civil Guard "Frontex") and 3/4 Public Services and Emergencies (local police, ambulances). The company had a staff of about 40 people, of which about $70 \%$ were young and highly qualified technicians. First contract: supply of a mobile location system to the Paris Police Department: CNMV, 83,671, 6/9/2007.

${ }_{17}$ CNMV, 23.585 30/5/2007. In its basic lines, the Amper Group's Strategic Plan (2005-07) sought growth - organic growth in business volume with a sustained annual average rate of $10 \%$ - an increase in profitability, an increase in the gross operating margin (EBITDA/Sales) from $8.8 \%$ in 2004 to $10 \%$ in 2007 , multiplying the current ordinary result by at least 1.5 and continuing with the optimisation of working capital and the generation of a financial surplus: Grupo Amper, Información Económica y Financiera del Grupo, 2005, pp. 115-116.

${ }_{18}$ Grupo Amper, Annual Report 2009, p. 11.

${ }^{19}$ Eurocopter helicopters: Tiger, NH-90 and civil helicopters; A400 aircraft and super tankers; location: Albacete Science and Technology Park and Aeropolis, Aerospace Technology Park of Andalusia: Amper, Report 2007, p. 24; Cinco Días, 1 September 2007; ABC, 22 May 2007. Amper and the Andalusian company Prevención de Riesgos y Calidad (Prescal) forged an agreement by which it would occupy spaces ceded by the Andalusian company in Aerópolis (Seville) in its $\mathrm{A} 400 \mathrm{M}$ avionics equipment engineering and maintenance centre. Prescal wanted to strengthen its position as a leading company in the Andalusian aeronautical market. Amper was initially to work along three main lines: to support the A400M plant (Final Assembly Line) in the testing and installation of the equipment supplied by Thales; to develop systems engineering with EADS-CASA and, finally, to offer companies R\&D services related to avionics and electronics for new equipment. The R\&D department was to be composed of engineers and technicians, mainly from the Universities of Cadiz and Seville, who would be trained for one year at the company Thales (Bordeaux), within the framework of an important technology transfer program: Andalucía, 3 July 2007 ; Aeronáutica Andaluza, 5, October-December 2007, p. 45. With the plant already open, key parts were manufactured abroad, as was the case with the wing set for Airbus (England), the fuselage (Airbus France) and the tail assemblies for the first aircraft: Europa Press, 4. May 2007.

${ }_{20}$ The strategic plan foresaw an increase in the weight of international sales from $35 \%$ in 2010 to $70 \%$ by the beginning of 2013 : Amper, Annual Report 2010, pp. 14 and 25 .
} 
elements of its business model. In the 2011/2013 strategic plan, internationalisation, efficiency and innovation were the driving forces behind the recovery in profitability.

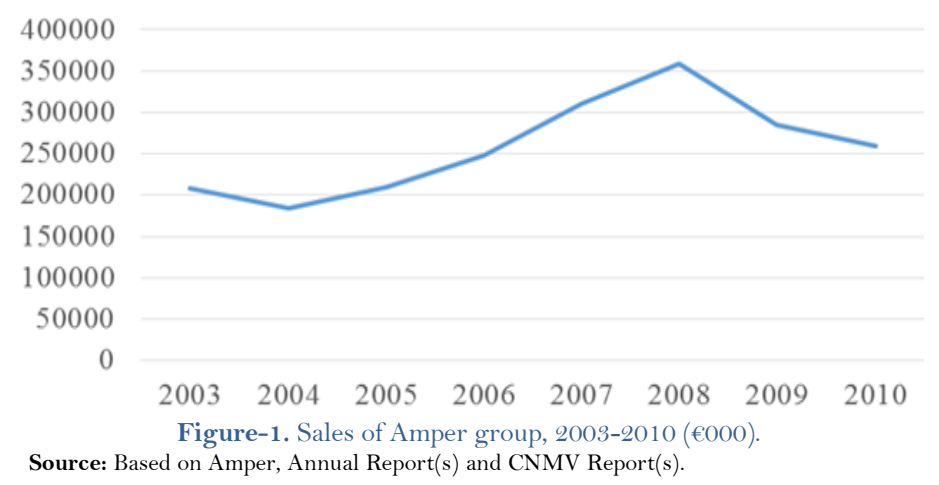

After a fall subsequent to the first restructuring, the Amper Group's sales in current terms grew until 2008 and then declined Figure 1. Its main customers were the public sector, with a percentage of around $44 \%$ of sales volume in 2003-2005, followed by Telefónica with around a third, private sector with an average of $21 \%$ and the other telecommunications operators. By geographical destination, sales were mainly in the domestic market (72.4\% in 2003), but exports showed greater dynamism so that in 2005-2006 they reached an average of $38 \%^{21}$. Amper relied on foreign markets and internationalization as an engine of growth. Figure 2 clearly shows the role of export substitution, mainly to the psychologically close area of Latin America. ${ }^{22}$.

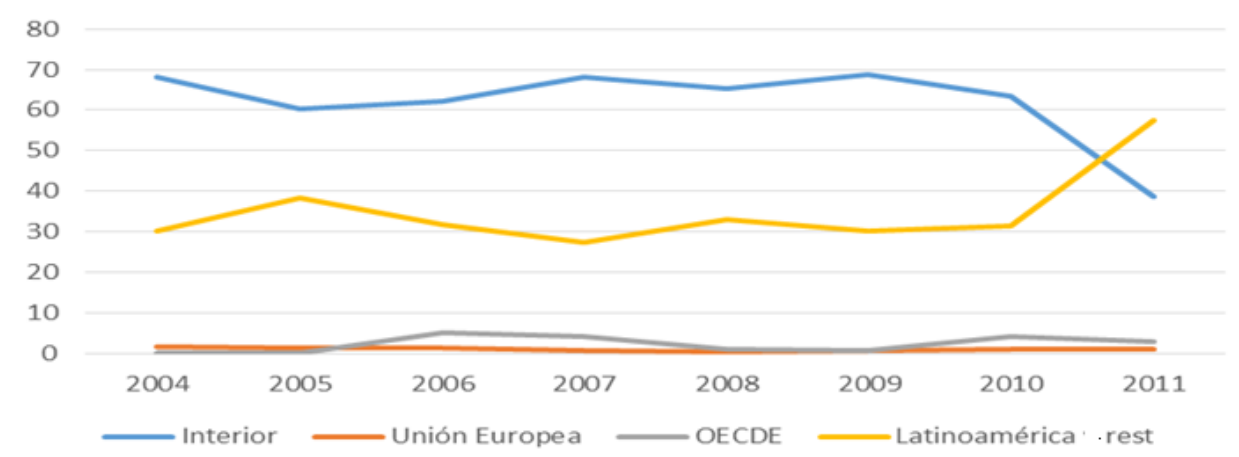

Figure-2. Breakdown of Amper markets by geographical area.

Source: Based on Amper, Annual Reports.

A milestone in the internationalisation process that closed the period under study was the acquisition of $85 \%$ of the North American company eLandia and its integration into Medidata, which increased Amper's presence in Latin America with 3,000 new industrial customers, including sixteen large telecommunications operators, and provided a platform for the business. In 2010, Amper's senior management remarked: "Our goal is not to be an international company, but a true multinational" 23 .

\section{Strategic Alliances and Agreements Reached}

Given the objectives, let's go to the means of achieving them. Amper's growth strategy was complemented by strategic alliances with third parties, whether they were temporary, aimed at a very specific objective, or of a longer-term nature. Amper had forged a culture of pacts very early on. Agreements such as those concluded between the end of 1975 and 1978 with the French PTTs for the supply of telephone answering machines contributed to this. They consisted essentially of a license to manufacture the equipment on the premises of

\footnotetext{
${ }^{21}$ Exports: $31 \%$ in 2009; $37 \%$ in 2010: Amper, Annual Report 2010, p. 18.

${ }^{22}$ Taking a few units separately, in 2009 IRS Brazil contributed a quarter of the group's total revenue, a percentage very similar to that of IRS Spain: Amper Group, Annual Report 2009, p. 20. Exporting not only contributes to sales growth but also provides additional advantages: diversification of the customer base with reduced dependence on a few major players; chances to match fluctuations in demand related to the regional business cycle; opportunities for product specialisation, unlikely in the narrow local market; and gaining experience through the network of contacts and partners: Recklies (2001), 1-3.

${ }^{23}$ Amper, Annual Report 2010, p. 12. In 2010 Amper had its headquarters in Madrid. By areas, the defence department was located in Getafe and two work centres in Albacete and Seville; the communications and security department in the surrounding of the capital (Tres Cantos and Getafe). It had delegations in eight Spanish cities on the peninsula and the islands -Algeciras, Oviedo, Barcelona, Bilbao, Palma de Mallorca, Valencia and several in Seville, as well as one in Getafe (Epicom). In Latin America, the headquarters of the communications and security area were located in twenty-four cities in fourteen countries (Miami; Buenos Aires (Argentina), Rio de Janeiro, Belo Horizonte, Porto Alegre, Sao Paulo, Brasilia and Barueri (Brazil); Bogota, Medellin and Cali (Colombia); San José (Costa Rica); Quito and Guayaquil (Ecuador); San Salvador (El Salvador); Guatemala City (Guatemala); Tegucigalpa (Honduras); Mexico (Mexico); Managua (Nicaragua); Panama City (Panama); Santo Domingo (Dominican Republic); Trinidad and Tobago (Trinidad); Caracas and Maracaibo (Venezuela): Amper, Annual Report 2010, pp. 60-62. In 2011, the Group had headquarters in Madrid, Sao Paulo and Miami and 38 offices in 22 countries: Amper, Annual Report 2012, p. 8.
} 
Compagnie de Signaux et d'Entreprises Électriques (CSEE), with a 4.5\% royalty, and the initial supply of complete equipment and parts or sub-assemblies when the company took over manufacturing on the industrial worksite ${ }^{24}$.

During 2005 Amper agreed with Motorola to consider the IRRINET system in irrigation projects. This "customised" technology was specially developed for irrigation and consisted of incorporating low consumption PLC remote stations with concentrator units and customisable SCADA. There was a growing market for this type of system whose demand for performance was not very high ${ }^{25}$.

In the field of control and management of unregulated borders, Amper led a consortium of 15 Spanish and foreign companies (Telven, Boeing, GMV and Isdefe, among others) and 25 research organisations to carry out the four-year INTEGRA project, a branch of the national CENIT programme and aimed at developing support and decision-making tools in $\operatorname{crises}^{26}$.

Together with INTEGRA, the most relevant research projects in Spain and Europe in which Amper participated were Tecamis+, Globe, IDS3D, Wolf and Sintonía. Amper was leading the TECAMIS+ R\&D project, which was working on a modular architecture development to take advantage of Internet functionalities. The project, worth 8 million euros over three years and subsidised by $11 \%$ with $50 \%$ public funding, was included in the Plan Avanza sponsored by the Ministry of Industry ${ }^{27}$ (Annual Report 2009).

GLOBE, which aimed to define the future border management system of the European Union and was funded, was endowed with 1.1 million euros. Amper led the work on non-regulated borders Annexe 2.

In the consortium mode, Amper collaborated with the Polytechnic University of Valencia and a group of European companies in the development of the MARIUS program, financed by the European Union within the European Security Program and aimed at defining and designing a European system for the integration of sensors and for the fusion of data in an airborne platform whose purpose is crisis management. In this European project, Amper provided the command and control system²8 (Annual Report 2006).

In the area of integration of IP Telephony and Unified Communications and Collaboration Platforms in Spain, Amper allied with Microsoft to market contact centre solutions after obtaining Voice Partner accreditation. Amper developed a business and technical training plan over a year and with the involvement of all the unit's departments. At the same time, it built the service offering related to Microsoft's unified communications platform ${ }^{29}$.

A close relationship with the operator Telefónica afforded Amper market opportunities. It was the case with the collaboration agreement with the British company Detica to develop a Logical Security project in Telefónica Annexe $2^{30}$. At home, a strategic agreement with the telephone operator gave way to a first contract to sale in South America a piece of flexible personal cryptography equipment for GSM ${ }^{31}$.

An example of an alliance was with Chertoff Group, a safety and risk management consulting company led by a former Bush administration official. The agreement aimed at joint business development and project execution in the field of homeland security -border control, 112 emergency centres and critical infrastructure protection- in the United States and other international markets. Besides, the Chertoff Group was to help Amper SA to establish partnerships with leading U.S. companies to pursue specific business opportunities in the various security programs at federal and state levels ${ }^{32}$.

In partnership with fifty research organisations and companies, Amper developed technologies applicable to unmanned aircraft or drones within the framework of the Sintonia project (Unmanned Systems Oriented to Zero Environmental Impact) and the Cenit-E program of the Ministry of Industry, financed by the CDTI. The entreprise was responsible for coordinating and researching formulas to optimize the transmission of sensor data in the ships and solutions to carry out the launch and recovery of the unmanned aircraft automatically and safely ${ }^{33}$.

The alliances were sometimes based on the performance of the subsidiaries. This was the case when Amper and Elandia, a leading provider of products and services, entered into a regional alliance through their

\footnotetext{
${ }^{24}$ Amper won the competition with the CM-52 model, the second generation of the CM-5 equipment supplied to CTNE, and after two years renewed another contract for the supply of a new version, the CM-60: Rico, César, "Notas", Communication to the author, June 25, 2020. CSEE would be considered as a giant engineering office, with half a thousand highly qualified engineers: Les Échos, 10 September 1991.

${ }_{25}$ Amper, Memoria, 2005, p. 33. Motorola advertised its IRRInet M as a total water management platform with a flexible radio or cellular wireless field terminal unit capable of advanced irrigation and water management control.

${ }^{26}$ INTEGRA had an overall budget of $€ 28.4$ million, half of which was funded by the CENIT Programme. The tools it used presented simulations of different scenarios that served to automate decision-making processes: Amper, Annual Report 2009, p. 55. The Council of Ministers authorized a grant: Amper, Annual Report 2008, p. 2. Abengoa claimed Telvent's leadership in the INTEGRA project for migration management. Amper Sistemas S.A. was awarded a grant for the Land Border Surveillance System project within the Information Society Research and Development Program: Resolution of March 2, 2005, from the Directorate General for the Development of the Information Society, BOE, 84, April 8, 2005, p. 12,283.

${ }^{27}$ Amper, Informe 2009, p. 55.

28 Amper, Annual Report 2006, p. 27

${ }^{29}$ El Economista, 5 April 2006.

so Informe Anual 2009, pp. 4-5.

${ }^{31}$ Cryptography equipment was the $670 \mathrm{E}$ system, which could be used with any type of GSM terminal and provided a very high degree of confidentiality: Amper, Memoria 2007.

32 Amper, S.A. sought to exceed 200 million euros in international Homeland Security trading over the following three years: CNMV, 115,970, 9/11/2009; Amper, Annual Report, 2009, p. 45; El Economista, 10 November 2009. As part of the agreement, Chertoff Group was to take a 0.59 per cent stake in Amper, S.A., which could come from the company's freely disposable treasury stock. Chertoff Group validated the safety technology by partnering with Amper: Amper, Annual Report 2009, p. 12.

${ }^{33}$ Partners: Indra, Sener, Aernova, Cesa, Aries Complex or Insa, among others: Cinco Días, 15 September 2010.
} 
respective subsidiaries Medidata and Desca Holdings to leverage the strengths of both and compete throughout Latin America as one of the largest regional providers of information and telecommunications products along with capabilities and operations. Elandia and Amper were also committed to developing a joint sales effort aimed at regional and multinational customers in the same geographical area. The alliance also supported the sales efforts of Amper's entire product portfolio in its three business divisions (Defence, Homeland Security and Telecommunications) throughout Latin America. For Elandia, the alliance was also to support the expansion of its education business through CTT in Brazil ${ }^{34}$. In another specific agreement, the Delaware-based U.S.A. company transferred control of its subsidiaries' licenses in Advanced Wireless Service to $\operatorname{Amper}^{35}$ (Federal Communications Commission, 2010).

By the strategy of incorporating new geographical areas, in 2010, Amper negotiated with different Indian companies in the double direction of tackling joint projects and optimising their own technological products. In this category belonged an agreement with a local partner-Mistral Solutions- with the double objective of introducing their emergency and mobility products in India and to reduce the production cost of the local industry through advanced technological solutions ${ }^{36}$.

Under collaborative schemes of a cross-cutting nature, Amper developed the I-3D project together with two entities with very different characteristics, the Polytechnic University of Madrid and the business consultancy Novagenia Information Technologies. The project, financed by the Government, aimed to develop a three-dimensional portal for identification and monitoring in controlled environments ${ }^{37}$.

Up to four times between 2003 and 2005, Amper partnered with national and international companies to take part in competitions with a potential for success. Twice it did so as a parent company and the remaining two times through its subsidiaries Amper Programas and Amper Medidata. In the first case, it formed a joint venture with Telefónica to supply AENA and in the second, with Ofiteco and SICE, to maintain and sustain the automatic network in the Ebro basin. In the modality of operation through subsidiaries, Amper Programas and Amper Medidata joined forces with Cisco and Sun, Thales Communications AG and Hitachi Data Systems to fulfil the commitments of the contracts with the Swiss Army and in in São Paulo with Telefónica and the regional state (Prodesp) ${ }^{38}$ Annexe 2. To end a long list, not always easy to substantiate, Amper carried out numerous contracts with important clients in the services sector ${ }^{39}$.

Amper collaborated with the COTEC Europe Foundation and other Spanish, Italian and Portuguese companies in a pioneering project aimed at developing technological systems to improve maritime and environmental safety and the interoperability of agencies in the Mediterranean.

The growth strategy adopted by the Group entailed the above-mentioned divestments, which were generally carried out after a major financial clean-up and adaptation of the workforce to the competitive environment Table $2^{40}$. In 2003, Amper Soluciones had already sold its Network Services to Intelsis, a unit that had been representing approximately $40 \%$ of its sales and half of its staff. This meant abandoning the activities directly related to the outsourcing of internal and external plant work for the fixed network of telecommunication operators. After this operation, the company maintained its business units of special projects, products, radio services and professional services. The subsidiary planned to focus on the product line, through its offer in the field of network access, which covered both terminals and equipment for end-users and the access equipment itself. In the services sector, its offer would focus on the engineering and installation of cellular or any other technology (LMDS, $\mathrm{PDH}, \mathrm{SDH}$, etc.) radio systems ${ }^{41}$.

Two further divestments followed in 2004. The first, the sale of Ibersegur, meant the definitive exit from the business of developing, manufacturing and selling parking management systems and parking meters.

\footnotetext{
${ }^{34}$ Desca Holdings, based in Miami, Florida, was a provider of network infrastructure and systems integration in the United States and 13 Latin American countries - Argentina, Colombia, Costa Rica, Ecuador, El Salvador, Guatemala, Honduras, Mexico, Nicaragua, Trinidad and Tobago, Panama, Perou, and Venezuela: EX-10.1 2 DEX101.HTM Strategic alliance agreement, 24 May 2010.

${ }_{35}$ Federal Communications Commission (2010); Elandia International Inc., Annual report for the fiscal year ending Friday, December $31,2010$.

${ }^{36}$ Amper, Annual Report 2010, p. 27. The nemesis EMS (Emergency Management System) was introduced. Amper transferred its emergency and mobility hardware solutions know-how to Mistral Solutions: El Economista, 26 May 2011. The agreement, admittedly, signed in 2011, followed an innovative costsharing scheme that allowed the Indian company to exclusively distribute Amper's security products in the region and to redesign and put these products into production worldwide: Amper, 2011 Report, p. 36-37. Mistral Solutions, based in Bangalore, India, was heavily focused on the design, development and manufacture of hardware and software solutions in the areas of defence, security and space, for companies in different countries, including the United States: ComputerWorld, May 27, 2011; Infodefensa, May 27, 2011.

${ }^{37}$ With funding within the Avanza R+D subprogram of the Ministry of Industry, this was a technological development that would allow the generation of virtual scenarios in real time in specific spaces such as infrastructure refineries ports security areas from data from fixed cameras deployed in the area to be controlled and other surveillance systems: Amper, Annual Report 2010, p. 40.

${ }^{38}$ Hitachi Data Systems was a joint venture between Hitachi Ltd. and Electronic Data System to compete with Amdahl: Computerworld, 8 May 1989

39 MUFACE, the General Social Security Treasury, prisons, universities (Cartagena, Cádiz, Complutense de Madrid), hotel chains such as Westin and property managers such as Richard Ellis. A few details are available. In the example of the University of Barcelona, the definition of a "framework of excellence" for the use of ICTs involved the design and implementation of a collaborative research network model with the highest technological performance. In the Social Security area, Amper renewed the telephone networks with Aastra technology in 460 sites and a total of 14,000 telephones, implemented management and pricing systems and deployed IP telephone systems in 300 sites with 1,200 IP telephones with a Next Generation Network connection: Annual Report 2009, pp. 80-81.

${ }^{40}$ The divestments comprise the disposal and sale of assets, facilities, product lines, subsidiaries, divisions and business units of the parent company: Moschieri and Mair (2008), pp. 399-422; Borga, Ibarlucea-Flores, and Sztajerowska (2020), p. 1.

${ }^{41}$ Other technologies were LMDS, PDH, SDH, etc. The enterprise offered a range of advanced products (ADSL, Wifi, etc) for fixed and mobile network operators. Sales on the last day of March 2004 reached $€ 9.45$ million, which represented a fall of $17 \%$ over the previous year, due to the sale of the network services unit and the closure of the activity in Peru. On the other hand, the notable boost in strategic activities (special projects, products, radio services and professional services) more than met sales expectations. Homogeneous sales, without the effect of the sale of the network services unit, stood at $28 \%$ more than the $€ 7.37$ million in the same period last year.
} 
Before the end of the year, Amper Soluciones, S.A. sold to the investor American Pacific, S.A. its interest in the STC Group, Sistemas, Telecomunicación y Control, S.A., dedicated to the management of high and low capacity radio link projects. Following this operation, Amper Soluciones, a subsidiary dedicated to telecommunications operators in Spain, maintained its four business units for special projects, products, radio services and professional services. From now on, it focused on the niches with the best prospects in the telecommunications market ${ }^{42}$.

Table-2. Divestments of the Amper Group.

\begin{tabular}{|c|c|c|c|c|c|}
\hline Company & $\begin{array}{l}\text { Asset or interest } \\
\text { sold }\end{array}$ & $\begin{array}{l}\text { Buying } \\
\text { company }\end{array}$ & Year & $\begin{array}{c}\text { Price } \\
€ \text { million }\end{array}$ & Comments \\
\hline $\begin{array}{l}\text { Amper } \\
\text { Soluciones }\end{array}$ & Network Services & Intelsis & 2003 & 2.7 & \\
\hline $\begin{array}{l}\text { Amper } \\
\text { Soluciones }\end{array}$ & $\begin{array}{l}\text { Grupo STC, } \\
\text { Sistemas, } \\
\text { Telecomunicación y } \\
\text { Control, SA }\end{array}$ & $\begin{array}{l}\text { American } \\
\text { Pacific, SA }\end{array}$ & 2004 & 0.75 & $\begin{array}{l}\text { American Pacific } \\
\text { (management of } \\
\text { high and low } \\
\text { capacity radio } \\
\text { link projects) }\end{array}$ \\
\hline \multirow[t]{2}{*}{$\begin{array}{l}\text { Amper } \\
\text { Tecnologías }\end{array}$} & Ibersegur & $\begin{array}{l}\text { Societat } \\
\text { Catalana } \\
\text { d'Iniciatives }\end{array}$ & 2004 & 8.25 & \\
\hline & Networking to MSEs & - & 2003 & - & $\begin{array}{l}\text { closing to focus } \\
\text { on big business } \\
\text { (AENA) }\end{array}$ \\
\hline
\end{tabular}

\section{The Struggle for Competitiveness: Technological Capabilities}

Beyond the strategic agreements with technology leaders, it would have been difficult to keep Amper competitive internationally without dealing with technological development. From the very founding act of Amper, R\&D was an essential component of the company's raison d'être and, throughout its history, it had been reaffirming this distinctive facet. In 2010, the year in which this study ends, Amper occupied the fifth position in the ranking of Spanish companies by investment in research, development and innovation $(\mathrm{R}+\mathrm{D}+\mathrm{i})$. Within the strategic plans, objectives such as increasing profitability implied the adoption of specific measures, which in one way or another, concerned R\&D. To put the figures into perspective, Amper boasted that it devoted $12.1 \%$ of its turnover to investment in technology that could be used for R\&D. This high technological intensity aimed to achieve leadership and excellence in the markets in which it was present ${ }^{43}$.

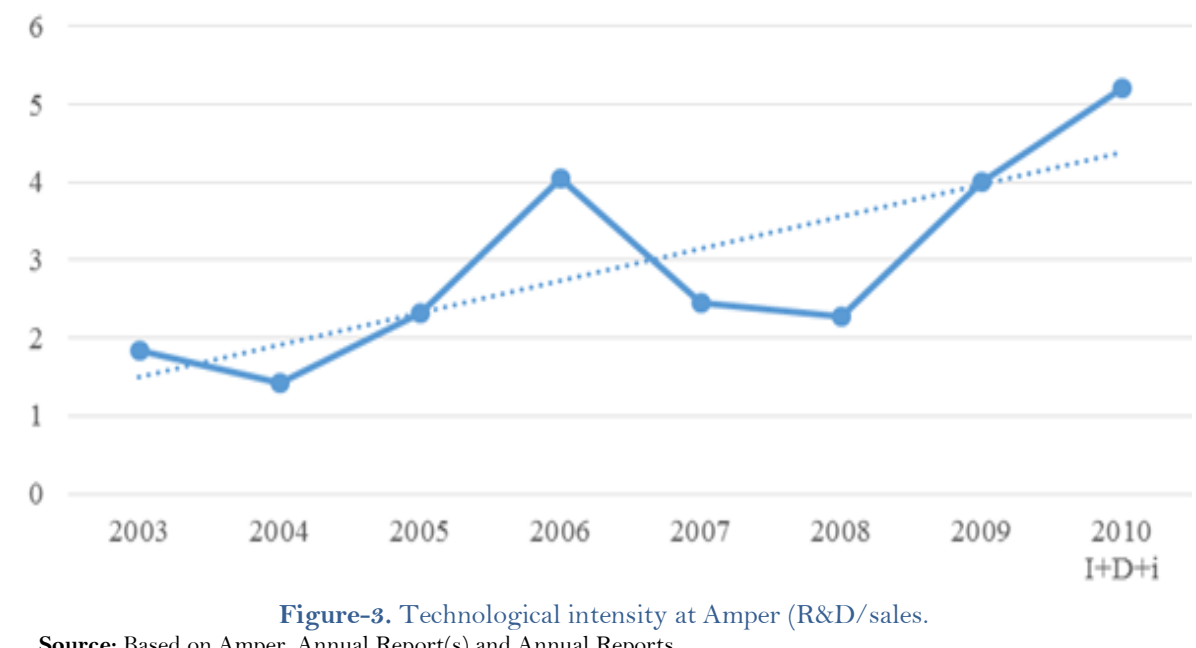

Seen as a whole, the years 2003-2010 show a growing trend in R\&D investment, with disparities that reached their lowest point in 2004 and their highest in the final year Figure 3. If we consider intangible assets, an indicator of $\mathrm{R} \& \mathrm{D}$, the composition of the known years shows a clear predominance of development effort,

42 American Pacific SA was a Spanish investment company with plans to enter the telecommunications market and highly qualified to relaunch the activities of the STC Group, which at the end of 2003 achieved a turnover of $€ 8.39$ million: CNMV, 50,621, 11/6/2004. This sale provided a significant capital gain. Amper Ibersegur contributed to the Amper Group's business at the end of the first half of 2003 with sales of $€ 5.67$ million and an attributable profit of $€ 0.39$ million: CNMV, 50.122, 28/5/2004, p. 3.

${ }^{43}$ Amper, Report 2005, p. 13; Amper, Report 2006, p. 27. 
with percentages of 67.92 and $83.81 \%$ in 2004-2005 and a more modest $46.42 \%$ in 2006 , because of the emergence of industrial property. The weight of computer applications was lower, with an average percentage of $20.89 \%$ of the total investment effort in 2004-2006 (Annexe 3 ) 44 .

Throughout 2007, with 7.61 million euros allocated to investments and R\&D\&I expenses and a team of 98 people, Amper completed the first operational development of the new crisis management system, which would allow it to strengthen its competitiveness in this market ${ }^{45}$.

The commitment to innovation in 2008 was recognised in the EU Industrial R\&D Investment Scoreboard ranking, prepared by the European Commission and led by Nokia in ICT, which placed Amper as the fifth Spanish company in terms of investment in R\&D\&I in relation to its number of employees and the eighth to its income. In Spain, Telefónica headed the ICT list and was ranked 40th in the world, while Indra Sistemas ranked $103 \mathrm{rd}^{46}$.

In 2009, Amper invested 12.65 million euros in R\&D\&I - 4\% of turnover - and dedicated more than 150 people to this activity. Amper achieved leading-edge solutions for command and control systems, emergency management, border protection and cryptosystems.

Within the overarching trend, it should be noted that the intensity varied substantially according to the Group's subsidiaries or sections. In the security and defence, the percentage of turnover that could be brought into R\&D was around 20\% R\&D\&I, respectively, with a share of the year's sales over $14 \%$ and $13 \%$. The bulk of these resources were allocated to the development of new generation equipment and products in the field of CIS systems, which would enable the company to maintain a leading position in a field on which it based its development strategy for the coming years ${ }^{48}$. In 2006, Homeland Security invested 1.1 million euro in R\&D (4.3\% of sales) and employed 12 people. Since the beginning of this year, it obtained public funding of 1.5 million euro to develop R\&D\&I projects. More specifically, the cryptosystems section focused its activity under the double perspective of the sale of national equipment of its own technology, to which other non-national ones (NATO) were added, and the development of R\&D\&I activities under contract. These activities represented 30\% of total sales for the year. The development of prototypes of new IP encryption systems was particularly important ${ }^{49}$.

As an example of technological capacity, Amper was equipped with transversal R+D instruments. Thus, it created the innovation unit with the task of ensuring the management and transfer of knowledge between the different units, the promotion and coordination of engineering activities and R\&D\&I initiatives and the maintenance and improvement of technological skills. At the end of 2006, the unit had 267 employees, 23\% of the total workforce, who were involved in developing its own products and executing high-tech contracts ${ }^{50}$.

In 2007 Amper took an important step in the configuration of its own technological capabilities with the launch of the amper.Lab, a highly sophisticated NEC networked experimentation centre that combined real equipment and virtual scenarios for the analysis of situations and operating scenarios. Through virtual simulation of the systems and equipment capacities, their effectiveness was checked and the necessary changes were programmed prior to the final design and implementation. Amper.Lab was set up to operate in connection with the network of twenty-nine similar centres scattered around the globe, leveraging their operational performance and their ability to respond to specific customer needs. The experimentation of defence and communications solutions found in it a key means of advancement. The amper.Lab showed its effectiveness in saving costs. During 2009, the centre launched the information and vetronics systems demonstrator for a new tactical vehicle ${ }^{51}$.

To these transversal R\&D instruments, Amper added a network of centres of excellence, engaged in R\&D of defence, communications and security solutions, advertised as the three strategic axes of Amper internationalisation, efficiency and innovation. The centres were located in the two largest Spanish cities Madrid and Barcelona - in an Asian city and another Latin American city - Bangalore and Bogota, respectively ${ }^{52}$.

The second source of accumulation of technical capacity consisted of the acquisition of intangible goods, a reality that was noted but insufficiently documented. We know, for example, that in two years (2004-2005)

\footnotetext{
${ }^{44}$ The investments in 2005 amounted to $€ 3.047$ million, of which almost a half came from internal developments and the rest from individual acquisitions: Deloitte (2005), p. 79

${ }_{45}$ Amper, Annual Report 2007, p. 21. NEC (Network Enabled Capabilities) are considered to be instruments to obtain additional capabilities for the development of military operations through the use of ICT: Defence and Security Technology Circle Foundation (2009), pp. 143-145.

${ }_{46}$ Repsol YPF ranked 183, Iberdrola 206, Acciona 213, Zeltia 242, Fagor Electrodomésticos 247 and Amper 646: European Communities (2009), p. 76; Amper, Report 2008, p. 12.

${ }_{47}$ Amper, Report 2005, p. 13

${ }^{48}$ Deloitte (2004) pp. 115-116; Amper (2004a) and Report 2005, p. 28.

${ }_{49}$ The projects "Multisensor Data Fusion" for the Autonomous Community of Madrid within the Madrid Innova Plan and "New C4 Architecture for More Open and Portable Borders" financed with PROFIT funds stand out: Amper, Report 2006, p. 32. The unity Homeland Security was preparing the commercial launch of one of the fastest IP crypts on the world market and had a personal crypt ready to connect to any state-of-the-art GSM phone; 2.3 million and a staff of 20 were allocated to the new IP cyphers.

50 Amper, Report 2006, p. 16

${ }^{51}$ Amper, Report 2007, p. 24 and Report 2010, p. 43. The demonstrator allows the joint operation of the vehicle systems with the real systems in operation in the Army: Amper, Annual Report 2009, pp. 54-55.

52 Amper, Annual Report 2012, p. 23. Obviously, the Bangalore site was closely related to the agreement with Mistral Solutions.
} 
payments were made for intangible assets, a concept that corresponds in part to R\&D. We also know that in 2005 individual acquisitions amounted to half of the total of 3,047 thousand euro ${ }^{53}$.

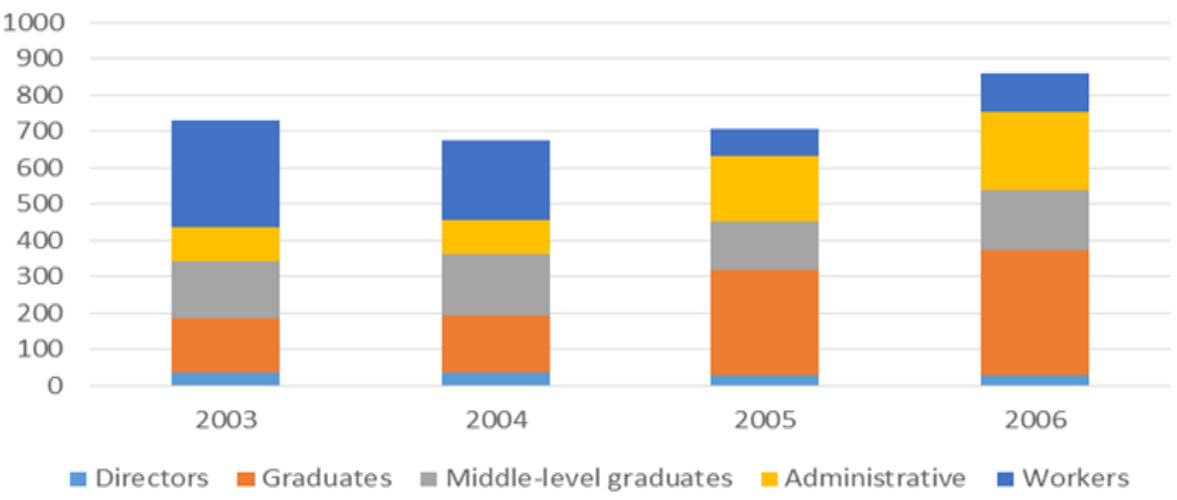

Figure-4. Breakdown of staff by professional category, 2003-2006.

Source: Based on Amper, Annual Report(s).

The accumulation of technical capacity stemmed thirdly from the high level of qualification of the workforce. In 2003-2011, the number of staff increased by a factor of 2.6. In only four years, between 2003 and 2006, employment adjustments, divestments and acquisitions contributed to a turnaround in the employment situation in the company. In 2006, almost $60 \%$ of the workforce were graduates, $40 \%$ of whom were higher education graduates, almost twice as many as in 2003, just the other side of the coin of what happened to the workers. A less significant part of the technical capacity was represented by the directors, who went from 5\% to 3\% Figure 4. This facet of Amper was partly the result of applying selective recruitment. During 2003-2005, over three-quarters of new hires were high-tech specialists, almost half were engineers and university graduates, and $31 \%$ were technical engineers and mid-level graduates ${ }^{54}$.

In 2011, the staff was made up of professionals with experience in the sector and qualified - 54\% had a university degree and $37 \%$ were technical specialists. Selective recruitment, together with an intense and constant generational renewal, resulted in a renewal of the staff. In 2005, the average age of Amper's staff was 41. In 2008, just over half the staff was under 40, $28 \%$ was between 40 and 50 and the remaining $19 \%$ was in the over-50 age group. After three years, the average age was 38 and three quarters were under 45 ; four-fifths were male. In terms of geographical distribution, most were employed in 14 foreign countries (59.43\%), with Samoa, Brazil, Colombia, Venezuela and Mexico accounting for almost $43 \%$ of the total ${ }^{55}$.

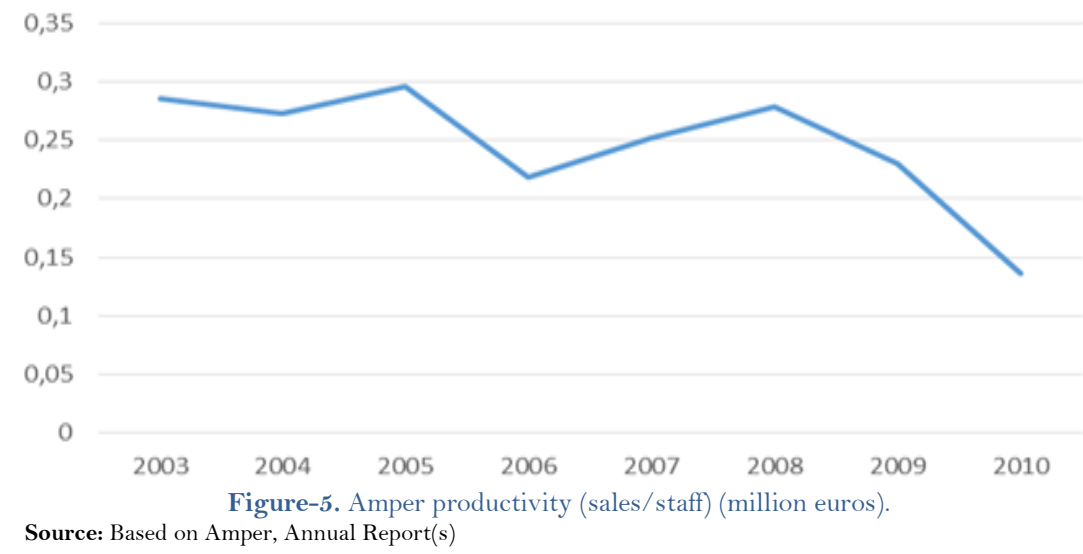

These data would naturally lead to qualify the results as positive in one of the decisive variables in the configuration of a successful company. However, Figure 5 tells us that this was not exactly the case, at least in the final years of the period under study, as shown by that first fall in 2006, just the year considered as the great transformation of the company, and the incontestable one of 2009. Two other significant variables income per employee and net profit per employee - performed poorly. Finally, throughout the years 20042010, only in two (2007 and 2008) did the productivity of assets improve and in three (2005, 2007 and 2008) did the return on assets grow. From another point of view, in 2007-2010 the average Free Cash Flow (FCF)

\footnotetext{
${ }_{53}$ There are references to subcontracting (10.2 and 29.76 million euros) in 2004-2005, without further specification: Deloitte (2005) p. 72. In the INTEGRA program, the Universidad Politécnica de Madrid participated as a subcontractor of Amper, cooperating in the task defined as Research in Technologies to assist in the execution and decision-making in C4ISR systems (Command, Control, Communications, Computers, Intelligence, Surveillance and Reconnaissance)

${ }_{54}$ Amper, Annual Report 2005, p. 13.

${ }_{55}^{5}$ In 2011, it dedicated 210 professionals to R\&D\&i: Amper, Annual Report 2011, p. 61
} 
was -0.48 million euros, and the average annual growth of $-10.72 \%$, according to analysts a sample of the company's inability to generate money from its business ${ }^{56}$.

Undoubtedly, the explanation, at least in part, lies in other figures that Amper presents, slightly modifying the previous criterion, which show a disqualification of the workforce. In the composition of the workforce by functions in 2010, engineering had lost its momentum (34\%), while operations were almost at the same level as in 2003 (38\%), something that is undoubtedly related to the opening of assembly plants in Seville and Albacete. The downgrading translated into a slight decrease in salary costs per employee. On the other hand, the profitability of the salary measured by the ratio income/expenses of personnel suffered a fall.

\section{Conclusion}

In general terms, this research brings key elements for a better knowledge of the survival strategies of companies in times of crisis, some of them, such as disinvestments, are not very well studied. It reveals the undeniable impact of the crises on companies, which were forced to implement survival strategies. In turn, it underlines that part of the solutions to the crises came precisely from those situations that accompanied the arrival of globalization. In reply to researchers' questions (Shin, 1990) this study sheds light on how to overcome size constraints and adopt more engaging modes of entry.

The research has focused on a case study of the evolution of an ICT company in Spain, characterised by its technological independence. During the years 2001 to 2003, as a consequence of the bursting of the technology bubble, Amper went through a deep crisis, which forced a restructuring and meant a significant reduction in its size. In this unfavourable world scenario, however, Amper managed to reduce the effects of the difficult economic situation and its turnover in Spain fell by $12.8 \%$ compared to the previous year ${ }^{57}$. In 2003 , Amper began to recover and the following year closed the adjustment period and even indicated new additions to the company, focused on frames with highly qualified technical profiles and oriented towards systems integration, the activity that contributed the most added values. From 2003 to 2006, sales and results returned to growth. At the end of 2006, Amper considered the need to undertake a process of profound change, to definitively overcome the legacy of the difficult years and place the company in a position to face the challenges of an increasingly complex and competitive market. Interestingly, the 2008 restructuring, which affected fifty people, seemed more oriented towards correcting inefficiencies ${ }^{58}$.

Through a long period of growth combined with successive restructurings, Amper became a company specialised in defence and security. In the process, it lost its character as a family business based on a niche market to become a multinational. The corporate purpose of Amper, unchanged since its incorporation in 1971, covered a wide variety of activities centred on telecommunications and electronic systems and equipment and their components - research, development, manufacture, repair, marketing, engineering, installation and maintenance - as well as a range related to movable and immovable property and securities ${ }^{59}$.

In short, the business model with own technology and internationalisation that Amper exemplifies achieved irrefutable results, but despite the company's generally triumphalist discourse, some figures speak of a return, insufficiency and unrealised results. However, analysts have continued to insist on its obvious international vocation and its firm commitment to innovative and excellent engineering.

\section{References}

Acs, Z. J., \& Yeung, B. (1999). Small and medium-sized enterprises in the global economy. Ann Arbor: University of Michigan Press.

Amper. (2004a). Information on the evolution and prospects of your business. $C N M V$.

Borga, M., Ibarlucea-Flores, P., \& Sztajerowska, M. (2020). Divestments by multinational enterprises. Investment Policy Insights, January 2020. 1-7.

Buckley, P. J. (1989). Foreign direct investment by small and medium sized enterprises: The theoretical background. Small Business Economics, 1, 89-100. Available at: https://doi.org/10.1007/978-1-349-11026-1_2.

Chen, M.-J., \& Hambrick, D. C. (1995). Speed, stealth, and selective attack how small firms differ from large firms in competitive behavior. Academy of Management Journal, 38(2), 453-482. Available at: https://doi.org/10.5465/256688.

Deloitte. (2004). Información económica y financiera del grupo Amper.

Deloitte. (2005). Economic and financial information of the Amper group.

Devore, M. R. (2013). Arms production in the global village: Options for adapting to defence-industrial globalization. Security Studies, 22(3), 532-572. Available at: https://doi.org/10.1080/09636412.2013.816118.

European Communities. (2009). The 2009 EU industrial RED investment scoreboard. Luxembourg: Office for Official Publications of the European Communities.

\footnotetext{
${ }_{56}$ The FCF, the amount of cash generated by a business after paying all expenses and capital investments, is considered one of the most significant and least manipulable indicators to determine the actual performance of a company.

${ }_{57}$ Annual Report 2009, p. 20; Amper, Annual Report 2007, p. 14.

${ }_{58}$ Amper, Annual Report 2004, p. 12. The bulk of the people affected by the restructuring - 40 - belonged to the IRS unit and the remainder to the corporate structure. The restructuring was carried out through a programme of redundancy and job amortisation. In total, non-recurring severance payments amounted to 5.4 million euro: Amper, Annual Report 2008, p. 58

${ }^{59}$ Amper Group, Consolidated report for the year 2004, p. 76.
} 
Federal Communications Commission. (2010). A comprehensive compilation of decisions (Vol. 26, pp. 2,074-072,083). Reports, Public Notices, and Other Documents of the Federal Communications Commission of the United States.

Hoyt, K. S. (2001). Technology hits the wall: The top 50 telecommunications equipment suppliers in 2000 (pp. 3-4). Boston MAS: Information Gatekeepers Inc.

International Monetary Fund. (2010). Perspectivas de la economía mundial. Washington: Fondo Monetario Internacional. Kalinic, I., \& Forza, C. (2012). Rapid internationalization of traditional SMEs: Between gradualist models and born globals. International Business Review, 21(4), 694-707. Available at: https://doi.org/10.1016/j.ibusrev.2011.08.002.

Kuo, H.-C., \& Li, Y. (2003). A dynamic decision model of SMEs' FDI. Small Business Economics, 20(3), $219-231$.

Moschieri, C., \& Mair, J. (2008). Research on corporate divestitures: A synthesis. Journal of Management छ Organization, 14(4), 399-422. Available at: https://doi.org/10.5172/jmo.837.14.4.399.

Nick, S. (1993). Business. Retrieved from: https://www.google.com/search?client=firefox-b-d\&q=Small++Multinationals.

OECD. (2003). OECD communications outlook. Paris: OECD.

OECD. (2007). Communications outlook. Paris: OECD.

OECD. (2010). OECD information technology outlook 2010. Paris: OECD.

$\mathrm{Pu}, \mathrm{H} .$, \& Zheng, Y. (2015). The FDI of small- and middle-sized enterprises (pp. 63-70).

Recklies, D. (2001). Small and medium-sized enterprises and globalization. The Manager Magazine, October, Recklies Management Project GmbH. Retrieved from: www.themanager.org.

Rosiere, S., \& Jones, R. (2012). Teichopolitics: Re-considering globalisation through the role of walls and fences. Geopolitics, 17(1), 217-234. Available at: https://doi.org/10.1080/14650045.2011.574653.

Shin, J. (1990). Micro multinational enterprises and the internationalization of small and medium sized enterprises: Contextual and organizational factors. Barcelona: Esade Business School.

Urata, S., \& Kawai, H. (2000). The determinants of the location of foreign direct investment by Japanese small and medium-sized enterprises. Small Business Economics, 15(2), 79-103.

Wolf, M. (2001). Will the nation-state survive globalization? (pp. 178-190): Foreign Affairs.

\section{Annexe-1. The Landata Group}

Landata Comunicaciones de Empresa provided installation, replacement, maintenance and upgrade services for customers of Telefónica's Ibercom network (voice networks, corporate converged voice-data applications, call centre systems, mobility solutions and support services). Exclusive contract with Ericsson for supplies to Telefónica (renewed in 2006 and valid until December 2007). Lanaccess focused its activity mainly on developing specific solutions (HW and SW) for transmitting and processing digital video. It also developed its products and solutions mainly related to surveillance/security applications. Revenues in 2005: €3.9 million; Ebitda: $€ 1.4$ million. Sales performance: products (35.9\%); customers: BBVA, Fichet, VSK, Securitas, etc.; services and maintenance: (13\%): BBVA, T-Systems, Unilever and La Caixa, among others. Nearly 80\% of revenues are linked to a mature product (OnSafe), with an upgrade planned for 2007 aimed at a larger base. Other products (SOS posts, Fiber Gate Swith) linked to infrastructure. Multi-standard, high-performance solutions that can be adapted to customer requirements. The Business Plan foresaw a 10.8\% annual growth rate in sales and a gradual improvement in profitability as a result of the greater weight of service and maintenance activities as well as operational leverage. The projected investment in CAPEX was around 1.2 million euros per year.

\begin{tabular}{|c|c|c|c|c|c|}
\hline Company & Customer & Year & Product or service & Price $€$ millions & Comments \\
\hline Amper & $\begin{array}{l}\text { Confederación } \\
\text { Hidrográfica } \\
\text { del Ebro } \\
\end{array}$ & 2003 & $\begin{array}{ll}\text { new } & \text { Tetra } \\
\text { communications } & \\
\text { network } & \\
\end{array}$ & & \\
\hline Amper & Presa de Itoiz & 2003 & $\begin{array}{l}\text { Emergency } \\
\text { Management System }\end{array}$ & & \\
\hline Amper & $\begin{array}{l}\text { Irrigation } \\
\text { communities of } \\
\text { Campo de } \\
\text { Cartagena }\end{array}$ & 2003 & $\begin{array}{l}\text { extension of the remote } \\
\text { control system }\end{array}$ & & \\
\hline $\begin{array}{l}\text { Temporary } \\
\text { Union of } \\
\text { Enterprises }\end{array}$ & $\begin{array}{l}\text { AENA- } \\
\text { Navegación } \\
\text { Aérea }\end{array}$ & 2003 & $\begin{array}{l}\text { Phase IV of the National } \\
\text { Air Navigation Data } \\
\text { Network (REDAN) }\end{array}$ & & $\begin{array}{l}\text { TUoE with } \\
\text { Telefónica }\end{array}$ \\
\hline $\begin{array}{l}\text { Amper } \\
\text { Programas }\end{array}$ & Swiss Army & 2004 & $\begin{array}{l}\text { information systems for } \\
\text { command and control of } \\
\text { the FIS HE programme }\end{array}$ & & $\begin{array}{l}\text { Partner with } \\
\text { Thales } \\
\text { Communicati } \\
\text { ons AG }\end{array}$ \\
\hline $\begin{array}{l}\text { Amper } \\
\text { Programas }\end{array}$ & Army & 2004 & $\begin{array}{l}\text { new version of the Basic } \\
\text { Area Network }\end{array}$ & Just over 21 & \\
\hline $\begin{array}{l}\text { Amper } \\
\text { Medidata }\end{array}$ & $\mathrm{ONO}$ & 2005 & $\begin{array}{lr}\text { Consulting } & \text { and } \\
\text { integration } & \text { of } \\
\text { multimedia services } & \end{array}$ & & $\begin{array}{l}\text { within the } \\
\text { planned } \\
\text { migration to }\end{array}$ \\
\hline
\end{tabular}




\begin{tabular}{|c|c|c|c|c|c|}
\hline & & & & & $\begin{array}{l}\text { your new IP } \\
\text { Network }\end{array}$ \\
\hline $\begin{array}{l}\text { Amper } \\
\text { Programas }\end{array}$ & AENA & 2005 & $\begin{array}{l}\text { hardware and software } \\
\text { tools for GBAS ground } \\
\text { data analysis }\end{array}$ & & $\begin{array}{l}\text { facilitar la } \\
\text { navegación } \\
\text { aérea basada } \\
\text { en satélite }\end{array}$ \\
\hline $\begin{array}{l}\text { Amper } \\
\text { Sistemas }\end{array}$ & $\begin{array}{l}\text { Abarán } \\
\text { (Murcia) }\end{array}$ & 2005 & $\begin{array}{l}\text { irrigation control } \\
\text { system using the most } \\
\text { advanced MOSCAD } \\
\text { technology from } \\
\text { Motorola }\end{array}$ & & \\
\hline $\begin{array}{l}\text { Amper } \\
\text { Sistemas }\end{array}$ & ENDESA & 2005 & $\begin{array}{l}\text { supply of } 400 \text { repeater } \\
\text { stations, } 1,500 \text { PMR } \\
\text { radio terminals, and } \\
\text { auxiliary equipment in } \\
\text { two years }\end{array}$ & & $\begin{array}{l}\text { to provide } \\
\text { communicati } \\
\text { ons service in } \\
\text { different } \\
\text { points of its } \\
\text { facilities }\end{array}$ \\
\hline Amper & $\begin{array}{l}\text { Estonian } \\
\text { Government }\end{array}$ & 2005 & border control system & & $\begin{array}{lr}\text { Plans } & \text { to } \\
\text { invest } & € 150 \\
\text { million in } 7 \\
\text { years }\end{array}$ \\
\hline $\begin{array}{l}\text { Amper } \\
\text { Medidata }\end{array}$ & $\begin{array}{l}\text { Compañía de } \\
\text { Procesamiento } \\
\text { de Datos del } \\
\text { Estado São } \\
\text { Paulo (Prodesp) } \\
\end{array}$ & 2005 & $\begin{array}{l}\text { Storage system, rental, } \\
\text { maintenance } \\
\text { installation of } \\
\begin{array}{l}\text { Lighting } \\
\text { subsystem }\end{array}\end{array}$ & & $\begin{array}{l}\text { In } \\
\text { partnership } \\
\text { with Hitachi } \\
\text { Data Systems }\end{array}$ \\
\hline Amper & Army & 2005 & $\begin{array}{l}\text { Maintenance of air } \\
\text { navigation instruments }\end{array}$ & 3 & $\begin{array}{l}\text { Instruments: } \\
\text { signalling, } \\
\text { communicati } \\
\text { ons and } \\
\text { electronics } \\
\text { for airplanes } \\
\text { and } \\
\text { helicopters }\end{array}$ \\
\hline Amper & $\begin{array}{l}\text { Serbia and } \\
\text { Montenegro }\end{array}$ & 2005 & border control system & 2,4 & $\begin{array}{l}\text { system } \\
\text { C4ISR }\end{array}$ \\
\hline Amper & AENA & 2005 & $\begin{array}{l}\text { Multiservice } \\
\text { telecommunications } \\
\text { network }\end{array}$ & over 15 & $\begin{array}{l}\text { New } \\
\text { Barcelona } \\
\text { Airport } \\
\text { Environment }\end{array}$ \\
\hline Amper & $\begin{array}{l}\text { Reconstruction } \\
\text { Agency } \\
\text { (Belgrade) } \\
\text { European } \\
\text { Union } \\
\end{array}$ & 2005 & $\begin{array}{l}\text { tactical land border } \\
\text { surveillance system }\end{array}$ & 2,4 & $\begin{array}{l}\text { screening of } \\
\text { illegal entry } \\
\text { (EuropeAid } \\
\text { Program) }\end{array}$ \\
\hline $\begin{array}{l}\text { Amper } \\
\text { Medidata }\end{array}$ & Ibermutuamur & 2005 & $\begin{array}{lr}\text { equipment } & \text { for } \\
\text { integrating voice } & \text { and } \\
\text { data networks } & \end{array}$ & & $\begin{array}{l}\text { Cisco teams, } \\
\text { call manager } \\
\text { and } \text { Cisco } \\
\text { Unity }\end{array}$ \\
\hline Amper & $\begin{array}{lr}\text { European } & \\
\text { Patent and } \\
\text { Trade Mark } \\
\text { Office }\end{array}$ & 2005 & $\begin{array}{ll}\text { Structured } & \text { Wiring } \\
\text { System } & \end{array}$ & & \\
\hline $\begin{array}{l}\text { Amper } \\
\text { Medidata }\end{array}$ & $\begin{array}{l}\text { Telefónica in } \\
\text { São Paulo }\end{array}$ & 2005 & $\begin{array}{l}\text { Deployment of } \mathrm{WiFi} \\
\text { network infrastructure }\end{array}$ & & $\begin{array}{l}\text { Partnership } \\
\text { with Cisco } \\
\text { and Sun }\end{array}$ \\
\hline $\begin{array}{l}\text { Amper } \\
\text { Medidata }\end{array}$ & Telefónica & 2005 & $\begin{array}{l}\text { Supply of the IP } \\
\text { Network (voice and } \\
\text { data) to the Government } \\
\text { agencies of the State of } \\
\text { Sao Paulo }\end{array}$ & & $\begin{array}{l}\text { It included } \\
\text { citizen's } \\
\text { centres, } \\
\text { schools, tax } \\
\text { collection, }\end{array}$ \\
\hline
\end{tabular}




\begin{tabular}{|c|c|c|c|c|}
\hline & & & & $\begin{array}{l}\text { penitentiaries } \\
\text {, etc. }\end{array}$ \\
\hline $\begin{array}{l}\text { Amper } \\
\text { Medidata }\end{array}$ & Telefónica & & $\begin{array}{l}\text { Cisco Metro Ethernet } \\
\text { Networks project, an } \\
\text { expansion of } \\
\begin{array}{l}\text { Backbone, ATM } \\
\text { network }\end{array}\end{array}$ & \\
\hline $\begin{array}{l}\text { Amper } \\
\text { Medidata }\end{array}$ & $\begin{array}{l}\text { Group Telmex } \\
\text { (Embratel) }\end{array}$ & 2005 & $\begin{array}{l}\text { providing a sun } \\
\text { microsystems } \\
\text { consolidation solution }\end{array}$ & \\
\hline $\begin{array}{l}\text { Amper } \\
\text { Medidata }\end{array}$ & $\begin{array}{l}\text { VIVO } \\
\text { (Telefónica } \\
\text { Móviles and } \\
\text { Portugal } \\
\text { Telecom) } \\
\end{array}$ & 2005 & $\begin{array}{l}\text { projects of readjustment } \\
\text { of regional networks } \\
\text { throughout Brazil and } \\
\text { expansion of the IP } \\
\text { Backbone }\end{array}$ & \\
\hline $\begin{array}{l}\text { Amper } \\
\text { Medidata }\end{array}$ & Petrobrás & 2005 & $\begin{array}{l}\text { Data network for the } \\
\text { new building }\end{array}$ & $\begin{array}{l}\text { Interconnecti } \\
\text { on of central } \\
\text { building } \\
\text { networks and } \\
\text { the } \\
\text { expansion of } \\
\text { several } \\
\text { networks }\end{array}$ \\
\hline $\begin{array}{l}\text { Amper } \\
\text { Medidata }\end{array}$ & $\begin{array}{l}\text { National } \\
\text { Development } \\
\text { Bank }\end{array}$ & 2005 & $\begin{array}{l}\text { headquarters data } \\
\text { network }\end{array}$ & \\
\hline $\begin{array}{l}\text { Amper } \\
\text { Medidata }\end{array}$ & Telemar & 2005 & $\begin{array}{l}\text { SUN servers for } \\
\text { mediation and billing } \\
\text { systems }\end{array}$ & \\
\hline $\begin{array}{l}\text { Amper } \\
\text { Medidata }\end{array}$ & Telemar & 2005 & $\begin{array}{l}\text { Sto-ragetek Corporate } \\
\text { Back Up System }\end{array}$ & \\
\hline $\begin{array}{l}\text { Amper } \\
\text { Medidata }\end{array}$ & Unibanco & 2005 & $\begin{array}{l}\text { Tagma state-of-the-art } \\
\text { storage system }\end{array}$ & $\begin{array}{l}\text { Hitachi data } \\
\text { systems }\end{array}$ \\
\hline $\begin{array}{l}\text { Amper } \\
\text { Medidata }\end{array}$ & Citibank & 2005 & $\begin{array}{l}\text { Data network to } \\
\text { interconnect credit } \\
\text { shops with }\end{array}$ & \\
\hline $\begin{array}{l}\text { Amper } \\
\text { Programas }\end{array}$ & Army & 2006 & $\begin{array}{l}\text { radio communications } \\
\text { equipment }\end{array}$ & \\
\hline Amper & $\begin{array}{l}\text { Military } \\
\text { Emergency } \\
\text { Unit }\end{array}$ & 2006 & $\begin{array}{l}\text { automatic mobile } \\
\text { communication system }\end{array}$ & $\begin{array}{l}\text { capable of } \\
\text { integrating } \\
\text { all } \\
\text { transmission } \\
\text { media used }\end{array}$ \\
\hline Amper & AENA & 2006 & $\begin{array}{ll}\text { radio-assisted } & \text { air } \\
\text { navigation systems } & \end{array}$ & $\begin{array}{l}\text { A } \\
\text { noteworthy } \\
\text { DVOR-DME } \\
\text { system (new } \\
\text { airport in } \\
\text { Huesca } \\
\text { (Aragón) }\end{array}$ \\
\hline Amper & AENA & 2006 & DME systems & $\begin{array}{ll}\text { Palma de } \\
\text { Mallorca } \\
\text { airport }\end{array}$ \\
\hline $\begin{array}{l}\text { Amper } \\
\text { Programas }\end{array}$ & Navy & 2006 & $\begin{array}{l}\text { radio communications } \\
\text { equipment }\end{array}$ & \\
\hline $\begin{array}{l}\text { Amper } \\
\text { Programas }\end{array}$ & Navy & 2006 & New system ILS-DME & $\begin{array}{l}\text { Fuerteventur } \\
\text { a airport } \\
\text { (Canaries) }\end{array}$ \\
\hline Amper & AENA & 2006 & $\begin{array}{l}\text { installation of } \text { an } \\
\text { advanced system for } \\
\text { satellite monitoring of }\end{array}$ & $\begin{array}{l}\text { Málaga } \\
\text { airport; pilot } \\
\text { character }\end{array}$ \\
\hline
\end{tabular}




\begin{tabular}{|c|c|c|c|c|c|}
\hline & & & navigation signals & & \\
\hline $\begin{array}{l}\text { Amper } \\
\text { Programas }\end{array}$ & Army & 2006 & radio sets & & $\begin{array}{l}\text { new } \\
\text { generation } \\
\text { PR4G V3 }\end{array}$ \\
\hline $\begin{array}{l}\text { Amper } \\
\text { Programas }\end{array}$ & Air Force & 2006 & $\begin{array}{lr}\text { Modernisation } & \text { of } \\
\text { communications } & \text { and } \\
\text { navigation systems } & \\
\end{array}$ & & Mirage F1 \\
\hline Amper & $\begin{array}{l}\text { Regional } \\
\text { Government of } \\
\text { Murcia (East) }\end{array}$ & 2006 & IT services & 1.4 & $\begin{array}{l}\text { first phase of } \\
\text { the Copicor } \\
\text { project }\end{array}$ \\
\hline Amper & Swiss Army & 2006 & $\begin{array}{l}\text { Command and Control } \\
\text { System (C2IS), updated } \\
\text { version }\end{array}$ & 12.6 & \\
\hline $\begin{array}{l}\text { Amper } \\
\text { Programas }\end{array}$ & & 2006 & $\begin{array}{l}\text { Command and Control } \\
\text { System (C2IS): final } \\
\text { version }\end{array}$ & over 43 & \\
\hline $\begin{array}{l}\text { Amper } \\
\text { Sistemas }\end{array}$ & $\begin{array}{l}\text { Madrid } \\
\text { Infraestructura } \\
\text { s de Transporte } \\
\text { (Regional } \\
\text { Government of } \\
\text { Madrid) }\end{array}$ & 2006 & trunking radio system & 3.2 & $\begin{array}{l}\text { North and } \\
\text { East Subway }\end{array}$ \\
\hline Amper & $\begin{array}{l}\text { Metro of } \\
\text { Madrid }\end{array}$ & 2006 & $\begin{array}{l}\text { Line } 3 \text { communication } \\
\text { networks, extensions } \\
\text { and new stations }\end{array}$ & & \\
\hline Amper & $\begin{array}{l}\text { Hydrographic } \\
\text { Confederations } \\
\text { of the rivers } \\
\text { Guadiana and } \\
\text { Ebro }\end{array}$ & 2006 & $\begin{array}{lr}\text { expansion, logistical } \\
\text { support and } \\
\text { maintenance of TETRA } \\
\text { Radio Communication } \\
\text { Systems }\end{array}$ & & \\
\hline Amper & $\begin{array}{ll}\text { Metro of } \\
\text { Madrid }\end{array}$ & 2007 & $\begin{array}{l}\text { Closed User Group } \\
\text { communications systems }\end{array}$ & & Canal station \\
\hline Amper & $\begin{array}{l}\text { Ministry of the } \\
\text { Interior }\end{array}$ & 2007 & & 2.6 & \\
\hline Amper & Civil Guard & 2007 & $\begin{array}{l}\text { maintenance and spare } \\
\text { parts for the SIVE } \\
\text { (Integral System of } \\
\text { Exterior Surveillance) }\end{array}$ & & \\
\hline Amper & AENA & & $\begin{array}{l}\text { supply and installation } \\
\text { of the TETRA network }\end{array}$ & 1.8 & $\begin{array}{l}\text { Barcelona } \\
\text { airport }\end{array}$ \\
\hline $\begin{array}{l}\text { Amper } \\
\text { Sistemas }\end{array}$ & Endesa & 2007 & $\begin{array}{l}\text { Tetra IP } \quad \text { network } \\
\text { deployment to } \\
\text { its analogue } \\
\text { network }\end{array}$ & & $\begin{array}{l}\text { Associated } \\
\text { with } \\
\text { Motorola; } \\
\text { Catalonia and } \\
\text { subsequent } \\
\text { expansion to } \\
\text { other parts of } \\
\text { Spain }\end{array}$ \\
\hline Amper & $\begin{array}{l}\text { Guardia Civil } \\
\text { (Civil Guard) }\end{array}$ & 2007 & $\begin{array}{ll}\text { Coastal } & \text { Surveillance } \\
\text { System } & \end{array}$ & & $\begin{array}{l}\text { Valencia and } \\
\text { Alicante } \\
\text { (Mediterrane } \\
\text { an) }\end{array}$ \\
\hline Amper & $\begin{array}{l}\text { Ministry of } \\
\text { Defence }\end{array}$ & 2007 & $\begin{array}{l}\text { PR4G combat radios } \\
\text { Annexe } 4\end{array}$ & 180 & \\
\hline $\begin{array}{l}\text { Amper } \\
\text { Programas }\end{array}$ & $\begin{array}{l}\text { Eurocopter } \\
\text { España }\end{array}$ & 2007 & communications & 9.1 & $\begin{array}{l}\text { Tactics - } \\
\text { VHF } \\
\text { (helicopters } \\
\text { TIGRE } \\
\text { HAD) }\end{array}$ \\
\hline Amper & $\begin{array}{l}\text { ENDESA, } \\
\text { AENA, Basque }\end{array}$ & 2007 & $\begin{array}{l}\text { crisis management and } \\
\text { digital radio }\end{array}$ & & \\
\hline
\end{tabular}




\begin{tabular}{|c|c|c|c|c|}
\hline & $\begin{array}{l}\text { Government, } \\
\text { Tetrapol } \\
\text { Network, } \\
\text { Police and Civil } \\
\text { Guard, } \\
\text { autonomous } \\
\text { communities } \\
\text { and city } \\
\text { councils; police } \\
\text { (Paris), } \\
\text { emergency } \\
\text { systems for } \\
\text { firefighters } \\
\text { (France); } 911 \\
\text { Control } \\
\text { Centres } \\
\text { (Mendoza, } \\
\text { (Argentina) }\end{array}$ & & $\begin{array}{l}\text { communication systems } \\
\text { (TETRA) }\end{array}$ & \\
\hline Amper & $\begin{array}{l}\text { Ministry of } \\
\text { Defence }\end{array}$ & 2007 & $\begin{array}{l}\text { development of a dual- } \\
\text { use crypto equipment }\end{array}$ & $\begin{array}{l}\text { three-year } \\
\text { contract, } \\
\text { according to } \\
\text { NATO } \\
\text { specifications } \\
\text { (IKMS) }\end{array}$ \\
\hline Amper & & 2007 & $\begin{array}{l}\text { personal cryptography } \\
\text { equipment for GSM }\end{array}$ & $\begin{array}{l}\text { equipment } \\
670 \mathrm{E}\end{array}$ \\
\hline Amper & AENA & 2008 & $\begin{array}{l}\text { Multiservice network } \\
\text { for the terminal and the } \\
\text { fire service }\end{array}$ & Ibiza Airport \\
\hline $\begin{array}{l}\text { Amper } \\
\text { (IRS) }\end{array}$ & $\begin{array}{l}\text { Companhia } \\
\text { Siderúrgica } \\
\text { Nacional } \\
\text { (Brazil) }\end{array}$ & 2008 & $\begin{array}{l}\text { implementation of the } \\
\text { new Network Security } \\
\text { structure }\end{array}$ & \\
\hline $\begin{array}{l}\text { Amper } \\
\text { (IRS) }\end{array}$ & Telesp & 2008 & $\begin{array}{l}\text { IP and corporate } \\
\text { backbone expansion }\end{array}$ & \\
\hline $\begin{array}{l}\text { Amper } \\
\text { (IRS) }\end{array}$ & $\begin{array}{l}\text { Euskaltel } \\
\text { (Basque } \\
\text { Country) } \\
\end{array}$ & 2008 & $\begin{array}{l}\text { renewal of the cable data } \\
\text { service } \\
\text { platform }\end{array}$ & $\begin{array}{l}\text { (cablemodem } \\
\text { s) }\end{array}$ \\
\hline Amper & Swiss Army & 2008 & $\begin{array}{l}\text { extension of the multi- } \\
\text { year contract (FIS HE } \\
\text { command and control } \\
\text { system) }\end{array}$ & \\
\hline Amper & $\begin{array}{ll}\text { Banco de } & \text { de } \\
\text { Santander } & \end{array}$ & 2008 & $\begin{array}{l}\text { Multiservice IP network } \\
\text { installation and } \\
\text { infrastructure provision }\end{array}$ & \\
\hline Amper & Civil Guard & 2008 & $\begin{array}{l}\text { Start of implementation } \\
\text { of a pilot project of the } \\
\text { SIGECRA Crisis } \\
\text { Management system }\end{array}$ & \\
\hline Amper & UME & 2008 & supply and operation & $\begin{array}{l}\text { Mérida and } \\
\text { León stations }\end{array}$ \\
\hline Amper & Army & 2008 & $\begin{array}{l}\text { new generation radio } \\
\text { equipment } \mathrm{PR} 4 \mathrm{G}-\mathrm{V} 3\end{array}$ & $\begin{array}{l}\text { production of } \\
\text { more than } \\
1.200 \\
\text { equipments }\end{array}$ \\
\hline Amper & Army & 2008 & $\begin{array}{l}\text { PNR-500 lightweight } \\
\text { radiotelephones; } \\
\text { vehicles equipped with } \\
\text { stations }\end{array}$ & $\begin{array}{l}\text { over } 5,000 \\
\text { radiotelephon } \\
\text { es and } \\
200 \text { vehicles } \\
\text { for } \quad 50 \\
\text { different } \\
\text { configuration }\end{array}$ \\
\hline
\end{tabular}




\begin{tabular}{|c|c|c|c|c|c|}
\hline & & & & & $\mathrm{s}$ \\
\hline Amper & $\begin{array}{l}\text { Regional } \\
\text { Government of } \\
\text { Extremadura }\end{array}$ & 2008 & $\begin{array}{l}\text { Development of the } \\
\text { corporate IP telephony } \\
\text { network }\end{array}$ & & \\
\hline Amper & $\begin{array}{l}\text { Extremadura } \\
\text { Health service }\end{array}$ & 2008 & $\begin{array}{l}\text { Development of the } \\
\text { corporate IP telephony } \\
\text { network }\end{array}$ & & \\
\hline $\begin{array}{l}\text { Amper } \\
\text { (Homeland } \\
\text { Security) }\end{array}$ & $\begin{array}{l}\text { Local police of } \\
\text { Elche (East) }\end{array}$ & 2009 & $\begin{array}{l}\text { Reinforcement } \\
\text { communication } \\
\text { infrastructures }\end{array}$ & & \\
\hline Amper & $\begin{array}{l}\text { Local police of } \\
\text { Vitoria (North) }\end{array}$ & 2009 & $\begin{array}{lr}\text { establishment } & \text { of } \\
\text { emergency } & \text { control } \\
\text { centres } & \\
\end{array}$ & & \\
\hline Amper & $\begin{array}{l}\text { Local police of } \\
\text { Telde (Canary } \\
\text { Islands) }\end{array}$ & 2009 & $\begin{array}{lr}\text { establishment } & \text { of } \\
\text { emergency } & \text { control } \\
\text { centres } & \\
\end{array}$ & & \\
\hline Amper & $\begin{array}{l}\text { Cuenca } \\
\text { Hidrográfica } \\
\text { del Ebro }\end{array}$ & 2009 & $\begin{array}{lr}\text { maintenance } & \text { and } \\
\text { conservation of the } \\
\text { automatic network }\end{array}$ & 13 & $\begin{array}{l}\text { UTE in } \\
\text { association } \\
\text { with Ofiteco } \\
\text { and SICE }\end{array}$ \\
\hline Amper & AENA & 2009 & $\begin{array}{l}\text { deployment of digital } \\
\text { radio communication } \\
\text { infrastructures }\end{array}$ & & $\begin{array}{l}\text { Alicante } \\
\text { Airoport }\end{array}$ \\
\hline Amper & $\begin{array}{l}\text { Banco } \\
\text { Santander }\end{array}$ & 2009 & $\begin{array}{l}\text { installation of the wiring } \\
\text { of the new DPC }\end{array}$ & & $\begin{array}{l}\text { Banco } \\
\text { Santander } \\
\text { Financial } \\
\text { City }\end{array}$ \\
\hline \multirow[t]{2}{*}{ Amper } & $\begin{array}{l}\text { European } \\
\text { Union }\end{array}$ & 2009 & $\begin{array}{l}\text { delivery of conclusions } \\
\text { on the feasibility of } \\
\text { creating a border } \\
\text { management system }\end{array}$ & & $\begin{array}{l}\text { GLOBE } \\
\text { project, with } \\
\text { an EU grant } \\
\text { under its FP7 } \\
\text { program }\end{array}$ \\
\hline & $\begin{array}{l}\text { Tarifa (Cádiz, } \\
\text { Andalusia) } \\
\text { border crossing }\end{array}$ & 2009 & $\begin{array}{l}\text { Installation of the } \\
\text { automatic number plate } \\
\text { identification system (in } \\
\text { Spanish, SIAM) }\end{array}$ & & $\begin{array}{l}\text { First of the } \\
\text { series }\end{array}$ \\
\hline Amper & AENA & 2009 & $\begin{array}{l}\text { Implementation of a } \\
\text { communications } \\
\text { network }\end{array}$ & & $\begin{array}{l}\text { Pioneering } \\
\text { network, } \\
\text { which } \\
\text { integrated all } \\
\text { the services } \\
\text { of the } \\
\text { installation }\end{array}$ \\
\hline Amper & $\begin{array}{l}\text { State security } \\
\text { forces }\end{array}$ & 2009 & $\begin{array}{l}\text { Start of development of } \\
\text { the Tecamis project }\end{array}$ & & $\begin{array}{l}\text { to develop a } \\
\text { new modular } \\
\text { architecture }\end{array}$ \\
\hline Amper & Mexico & 2009 & $\begin{array}{l}\text { communication and } \\
\text { emergency management } \\
\text { solutions }\end{array}$ & & $\begin{array}{l}\text { The "Safe } \\
\text { City" project, } \\
\text { the most } \\
\text { important in } \\
\text { the field of } \\
\text { security in } \\
\text { the great } \\
\text { capitals } \\
\text { around the } \\
\text { world }\end{array}$ \\
\hline Amper & Civil Guard & 2009 & $\begin{array}{l}\text { two fixed sensor SIVE } \\
\text { stations in Cádiz }\end{array}$ & & $\begin{array}{l}\text { Amper had } \\
\text { deployed } \\
\text { technology } \\
\text { along } 1,500 \\
\text { km } \quad \text { of } \\
\text { Spanish coast } \\
\end{array}$ \\
\hline
\end{tabular}




\begin{tabular}{|c|c|c|c|c|}
\hline Amper & $\begin{array}{l}\text { Autonomous } \\
\text { Government of } \\
\text { Valencia }\end{array}$ & 2009 & location systems & $\begin{array}{l}\text { in } \\
\text { firefighting } \\
\text { aircraft }\end{array}$ \\
\hline $\begin{array}{l}\text { Amper } \\
\text { Homeland } \\
\text { Security }\end{array}$ & Overall Spain & 2009 & $\begin{array}{ll}\text { The deployment } & \text { of } \\
\text { Levante's SIVE } & \text { is } \\
\text { completed } & \end{array}$ & $\begin{array}{l}\text { innovative } \\
\text { technology of } \\
\text { its crisis } \\
\text { management } \\
\text { system } \\
\text { (Nemesis) }\end{array}$ \\
\hline Amper & & 2009 & $\begin{array}{l}\text { extensions at the mouth } \\
\text { of the Guadalquivir } \\
\text { River and in Cadiz }\end{array}$ & $\begin{array}{l}\text { Nemesis } \\
\text { C4ISR } \\
\text { technology }\end{array}$ \\
\hline Amper & AENA & 2009 & $\begin{array}{l}\text { radio navigation aid } \\
\text { systems } \\
\text { equipment) }\end{array}$ & $\begin{array}{l}\text { airports of } \\
\text { Málaga, and } \\
\text { Tenerife Sur, } \\
\text { San Javier } \\
\text { and Lasso in } \\
\text { Canary } \\
\text { Islands }\end{array}$ \\
\hline Amper & $\begin{array}{l}\text { BcnRail Fair } \\
\text { (Barcelona) }\end{array}$ & 2009 & technological solutions & for transport \\
\hline Amper & Telefónica & 2009 & $\begin{array}{l}\text { Development of a } \\
\text { Logical Security }\end{array}$ & $\begin{array}{l}\text { associated to } \\
\text { the British } \\
\text { Detica; } \\
\text { first phase: } \\
\text { pilot test of a } \\
\text { network fault } \\
\text { detector }\end{array}$ \\
\hline Amper & $\begin{array}{l}\text { Rio de Janeiro } \\
\text { Metro (Brazil) }\end{array}$ & 2009 & $\begin{array}{l}\text { replacement and } \\
\text { expansion of its } \\
\text { communications } \\
\text { network }\end{array}$ & \\
\hline Amper & $\begin{array}{l}\text { Telefónica de } \\
\text { Chile }\end{array}$ & 2010 & $\begin{array}{l}\text { equipment for satellite } \\
\text { TV reception: antennas } \\
\text { and LNBs }\end{array}$ & $\begin{array}{l}\text { Direct } \quad \text { to } \\
\text { Home } \\
\text { satellite TV } \\
\text { in Latin } \\
\text { America }\end{array}$ \\
\hline Amper & $\begin{array}{ll}\text { Telefónica } & \text { de } \\
\text { Venezuela } & \\
\end{array}$ & 2010 & antennas and LNBs & \\
\hline Amper & $\begin{array}{l}\text { Castilla la } \\
\text { Mancha } \\
\text { Autonomous } \\
\text { Community } \\
\text { Health Service }\end{array}$ & 2010 & $\begin{array}{lcc}\text { deployment of } & \text { IP } \\
\text { telephony networks } & \end{array}$ & \\
\hline Amper & $\begin{array}{l}\text { Extremadura } \\
\text { Autonomous } \\
\text { Community } \\
\text { Health Service } \\
\end{array}$ & 2010 & $\begin{array}{l}\text { deployment of IP } \\
\text { telephony networks }\end{array}$ & \\
\hline Amper & $\begin{array}{l}\text { State } \\
\text { Emergency }\end{array}$ & 2010 & $\begin{array}{l}\text { IP technology of the } \\
\text { complex operation } \\
\text { centre and the expansion } \\
\text { of capacity of the digital } \\
\text { radio communication } \\
\text { system }\end{array}$ & \\
\hline Amper & $\begin{array}{l}\text { Emergencies, } \\
\text { Maule (Chile) }\end{array}$ & 2010 & $\begin{array}{l}\text { Pilot Emergency } \\
\text { Management Centre }\end{array}$ & $\begin{array}{l}\text { to analyse the } \\
\text { effectiveness } \\
\text { of a single } \\
\text { number for } \\
\text { emergencies }\end{array}$ \\
\hline Amper & $\begin{array}{lr}\text { Elche } & \text { City } \\
\text { Council } & \text { (East } \\
\text { of Spain) } & \\
\end{array}$ & 2010 & $\begin{array}{l}\text { local police secure } \\
\text { communications system }\end{array}$ & \\
\hline
\end{tabular}




\begin{tabular}{|c|c|c|c|c|c|}
\hline Amper & Army & 2010 & $\begin{array}{l}\text { new generation } \\
\text { command and control } \\
\text { systems }\end{array}$ & & \\
\hline Amper & $\begin{array}{l}\text { Metro of } \\
\text { Madrid }\end{array}$ & 2010 & $\begin{array}{l}\text { new digital mobile radio } \\
\text { communication system }\end{array}$ & 3,8 & TETRA \\
\hline Amper & $\begin{array}{lr}\text { Gijón } & \text { Port } \\
\text { Authority } & \\
\text { (North } & \text { of } \\
\text { Spain) } & \end{array}$ & 2010 & $\begin{array}{ll}\text { digital } & \text { radio } \\
\text { communications } & \\
\text { network } & \end{array}$ & 0,367 & $\begin{array}{l}\text { Improve care } \\
\text { during } \\
\text { emergencies } \\
\text { and } \\
\text { coordination } \\
\text { with other } \\
\text { services }\end{array}$ \\
\hline Amper & $\begin{array}{l}\text { Emergency } \\
\text { Medical } \\
\text { Assistance } \\
\text { Service, } \\
\text { Charente } \\
\text { Maritime } \\
\text { (France) }\end{array}$ & 2010 & $\begin{array}{l}\text { technology system to } \\
\text { integrate } \\
\text { communications systems }\end{array}$ & & $\begin{array}{l}\text { modernizatio } \\
\mathrm{n} \quad \text { and } \\
\text { enhancement } \\
\text { of emergency } \\
\text { management } \\
\text { and } \\
\text { communicati } \\
\text { ons systems }\end{array}$ \\
\hline Amper & $\begin{array}{l}\text { Ministry of } \\
\text { Defence }\end{array}$ & 2010 & $\begin{array}{l}\text { IP telephony services } \\
\text { over narrowband }\end{array}$ & & $\begin{array}{l}\text { type PR4G } \\
\text { compatible } \\
\text { with tactical } \\
\text { networks }\end{array}$ \\
\hline Amper & $\begin{array}{l}\text { Spanish Air } \\
\text { Force }\end{array}$ & 2010 & $\begin{array}{l}\text { systems for protection } \\
\text { and security in } \\
\text { international missions } \\
\text { (unattended sensors) }\end{array}$ & & $\begin{array}{l}\text { protection of } \\
\text { installations } \\
\text { by detection, } \\
\text { identification } \\
\text { and } \\
\text { classification } \\
\text { of possible } \\
\text { intrusions }\end{array}$ \\
\hline $\begin{array}{l}\text { Amper } \\
\text { Medidata }\end{array}$ & Telebras & 2010 & $\begin{array}{l}\text { IP network integration } \\
\text { solutions }\end{array}$ & over 10 & $\begin{array}{l}\text { Within the } \\
\text { National } \\
\text { Broadband } \\
\text { Plan }\end{array}$ \\
\hline Amper & $\begin{array}{l}\text { Government of } \\
\text { Mexico }\end{array}$ & 2010 & $\begin{array}{l}\text { supply of all } \\
\text { communications } \\
\text { integration platforms for } \\
\text { automatic integration of } \\
\text { voice and data between } \\
\text { citizens and users and } \\
\text { operators of emergency } \\
\text { systems }\end{array}$ & & $\begin{array}{l}\text { within the } \\
\text { project } \\
\text { Mexico safe } \\
\text { city }\end{array}$ \\
\hline Amper & $\begin{array}{l}\text { Flight } \\
\text { Technologies } \\
\text { (Brazil) }\end{array}$ & 2010 & $\begin{array}{l}\text { Supply of equipment and } \\
\text { information capture } \\
\text { management tasks }\end{array}$ & & $\begin{array}{l}\text { for drones in } \\
\text { spy and } \\
\text { border } \\
\text { control } \\
\text { operations }\end{array}$ \\
\hline Amper & $\begin{array}{lr}\text { Armed } & \text { Forces } \\
\text { United } & \text { Arab } \\
\text { Emirates } & \end{array}$ & & $\begin{array}{l}\text { command and control } \\
\text { system }\end{array}$ & 92 & \\
\hline
\end{tabular}




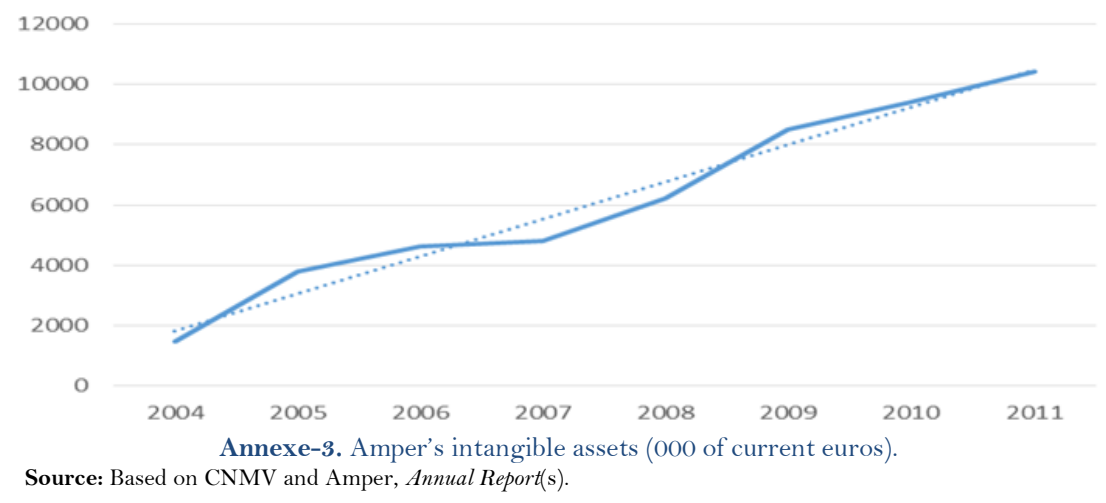

Annexe-4. The Army as a customer of Amper.

In 1992, the Spanish Army began to replace portable radio equipment and those installed in vehicles with a new generation radiotelephone that allowed for greater security in communications. The system selected was the PR4G radio from the company AMPER. Since then, equipment was purchased in versions 1, 2 and 3, although the first two were modernised. Version 3 was equipped with numerous Army units and vehicles and the new acquisition was intended to complete the equipment of those units lacking them, in order to guarantee communication between units and to unify and optimise radio resources. The Agreement involves the acquisition of tactical radio telephones of the PR4G family, as well as the accessories necessary for their operation, antennas, racks, wiring, etc.: CNMV, Madrid, 10 September 2007. 